\section{Smith ScholarWorks}

$1-1-2019$

\section{Loss of a Foundation Species, Eastern Hemlock (Tsuga canadensis), May Lead to Biotic Homogenization of Fungal Communities and Altered Bacterial Abundance in the Forest Floor}

\author{
Aliza Fassler \\ Smith College \\ Jesse Bellemare \\ Smith College, jbellema@smith.edu \\ Danielle D. Ignace \\ Smith College
}

Follow this and additional works at: https://scholarworks.smith.edu/bio_facpubs

Part of the Environmental Sciences Commons, and the Other Ecology and Evolutionary Biology Commons

\section{Recommended Citation}

Fassler, Aliza; Bellemare, Jesse; and Ignace, Danielle D., "Loss of a Foundation Species, Eastern Hemlock (Tsuga canadensis), May Lead to Biotic Homogenization of Fungal Communities and Altered Bacterial Abundance in the Forest Floor" (2019). Biological Sciences: Faculty Publications, Smith College, Northampton, MA.

https://scholarworks.smith.edu/bio_facpubs/209

This Article has been accepted for inclusion in Biological Sciences: Faculty Publications by an authorized administrator of Smith ScholarWorks. For more information, please contact scholarworks@smith.edu 


\title{
Loss of a Foundation Species, Eastern Hemlock (Tsuga canadensis), May Lead to Biotic Homogenization of Fungal Communities and Altered Bacterial Abundance in the Forest Floor
}

\author{
Aliza Fassler ${ }^{1, *}$, Jesse Bellemare ${ }^{1}$, and Danielle D. Ignace ${ }^{1}$
}

\begin{abstract}
Tsuga canadensis (Eastern Hemlock) is a key forest foundation species that is currently declining across the eastern US due to attack by exotic insect species, primarily Adelges tsugae (Hemlock Woolly Adelgid). In the northeastern US, declining Eastern Hemlock stands are typically replaced by fast-growing deciduous Betula lenta (Black Birch) trees, altering ecosystem processes and ecological communities. In this study, we used an approach that substituted space for time to explore how the forest floor's soil organic horizon, macrofungal communities, and bacterial abundance might be altered following Eastern Hemlock replacement by Black Birch. We compared intact, mature Eastern Hemlock forest plots at 2 sites in western Massachusetts to adjacent areas of vigorous regeneration of young Black Birch triggered by logging activity at the sites $\sim 25-30$ years ago. Forest-floor soil organic horizons were significantly thicker under Eastern Hemlock forests and exhibited a higher carbon:nitrogen $(\mathrm{C}: \mathrm{N})$ ratio, suggesting slower decomposition and greater accumulation of organic material under Eastern Hemlock compared to deciduous Black Birch canopies. Macrofungal communities emerging from the forest floor did not differ strongly in morphospecies richness between Eastern Hemlock and Black Birch plots. However, a greater number of rare fungi taxa, defined in this study as those represented by a single observation, were detected in Eastern Hemlock plots, and the composition of Black Birch plots was more homogenized and less variable. The abundance of bacterial colony forming units (CFUs) in the soil organic horizon appeared to follow a seasonal pattern of variation between mature Eastern Hemlock versus young Black Birch plots; CFUs were most abundant in Black Birch soils in the fall, potentially tracking input of new deciduous leaf litter, whereas Eastern Hemlock plots had higher CFU counts in the summer. The results of this study suggest that forest-floor characteristics will be substantially altered by the impending loss of Eastern Hemlock, associated macrofungal communities may become simplified and homogenized, and the timing of peak bacterial abundance in the forest floor might be shifted to the fall.
\end{abstract}

\section{Introduction}

In the forests of the eastern US, exotic insect pests and pathogens have been one of the primary drivers of ecosystem and community change (Ellison et al. 2005; Ignace et al. 2018; Lovett et al. 2006, 2016; Zukswert et al. 2014). These novel threats negatively impact biodiversity, alter ecological interactions, and can disrupt ecosystem processes and services (Hicke et al. 2012; Jackson and Bellemare

\footnotetext{
${ }^{1}$ Department of Biological Sciences, Smith College, Northampton, MA 01063. *Corresponding author - alizamfassler@gmail.com.
}

Manuscript Editor: Roland de Gouvenain 
2018; Lovett et al. 2006, 2016; Weed et al. 2013). In cases where these exotic pests and pathogens target distinctive foundation species, such as dominant tree species with unique effects on understory conditions, the communities developing in their wake are likely to be homogenized and overall landscape-scale diversity might be reduced (Ellison et al. 2016, Foster 2014). This wave of biotic homogenization, whether triggered by invasive species, human disturbance, or other environmental changes, is of major concern globally, and is considered a top threat to biodiversity preservation in coming decades (Ellison et al. 2016, McKinney and Lockwood 1999, Olden 2006, Olden et al. 2004).

Among the numerous northeastern US tree species impacted by exotic pests and pathogens, Tsuga canadensis (L.) Carrière (Eastern Hemlock) stands out as particularly consequential (Ellison et al. 2005, Orwig and Foster 1998). Hemlocks are currently threatened by 2 exotic insect pests introduced from eastern Asia, Adelges tsugae Annand (Hemlock Woolly Adelgid; HWA) and Fiornia externa Ferris (Elongate Hemlock Scale; EHS) (Ellison et al. 2005, Orwig et al. 2002). These insects, particularly HWA, trigger decline or mortality of infested hemlocks, and have led in recent decades to the collapse of unique, hemlock-dominated forest stands across many parts of the tree species' eastern US range (Eschtruth et al. 2006, Orwig and Foster 1998, Webster et al. 2012). Eastern Hemlock is considered a foundation species in the eastern US (Ellison et al. 2005), as the species creates distinctive forest understory conditions, significantly influences ecosystem processes, and is associated with unique elements of biodiversity dependent on the distinctive habitats it supports (Ellison et al. 2005, Ignace et al. 2018, Jackson and Bellemare 2018, Zukswert et al. 2014). Eastern Hemlock often occurs as a dominant canopy species on sites with nutrient-poor soils (Carey 1993, Rogers 1978), and can reportedly enhance these environmental conditions through the production of acidic, nutrient-poor leaf litter (Ellison et al. 2005; Finzi et al. 1998a, 1998b). In addition, the species' dense canopy of evergreen needles creates cooler, lower light conditions in the understory, different from those found under deciduous tree canopies (Ellison et al. 2005).

Although Eastern Hemlock-associated conditions appear to be unfavorable to many vascular plant species (Ellison et al. 2016), some non-vascular bryophytes likely depend on the tree's presence (e.g., Jackson and Bellemare 2018), and several animal species have been positively linked to Eastern Hemlock forest environments, including birds, salamanders, benthic invertebrates, and forest-floor mesofauna (Brooks 2001, Snyder et al. 2002, Tingley et al. 2002, Toenies et al. 2018, Zukswert et al. 2014). Less is known about the role of Eastern Hemlock in supporting unique fungal and microbial communities in the forest floor, but the distinctive ecosystem created by Eastern Hemlock, including deeper and more acidic soil organic horizons, should influence these species as well, particularly those directly involved in decomposition and nutrient cycling (Ignace et al. 2018, Orwig et al. 2013).

The impending loss of Eastern Hemlock from large parts of its native range may homogenize forest communities, as the distinctive conifer is often replaced by 
deciduous tree species, not other conifers (Ellison et al. 2005, 2016; Orwig and Foster 1998). For example, researchers have predicted that communities of birds and arthropods, including ants, will be simplified and homogenized by the loss of this foundation species (Ellison et al. 2005, 2016; Rohr et al. 2009; Toenies et al. 2018). Similarly, Jackson and Bellemare (2018) found that Eastern Hemlock decline could result in the loss of a distinctive bryophyte species, the liverwort Bazzania trilobata (L.) Gray. Although these community shifts might not always result in local declines in plot-scale diversity or richness (e.g., Cleavitt et al. 2008, Eschtruth et al. 2006), as other species such as forest generalists, exotics, and disturbance-dependent species could replace specialists, the net effect on landscape-scale diversity is predicted to be negative and could result in overall homogenization (Ellison et al. 2016, Foster 2014).

In the northeastern US, the loss of evergreen Eastern Hemlock has typically resulted in its replacement by deciduous Betula lenta L. (Black Birch), a fastgrowing tree species with divergent effects on the forest understory environment and edaphic conditions (Cobb 2010, Ignace et al. 2018). Hemlock-dominated stands typically develop a deep, acidic organic horizon and are characterized by slow decomposition and nutrient cycling, whereas, in contrast, stands dominated by Black Birch or other broad-leaved deciduous trees tend to exhibit higher rates of decomposition, greater soil respiration, faster nutrient cycling, and a diminished soil organic horizon (Cobb 2010, Finzi et al. 2014, Ignace et al. 2018, Jenkins et al. 1999). Hemlock-dominated ecosystems are generally characterized by having low and slow N-cycling due to the tree's low concentration of nitrogen in its foliage and litter, which results in soils with low extractable $\mathrm{N}$ pools, and low rates of potential net mineralization and nitrification (Finzi et al. 1998a, Lovett et al. 2004). For example, at sites in Connecticut, the soil C:N ratio was higher and the soil $\mathrm{pH}$ was lower under Eastern Hemlock forests than under canopies of deciduous trees (Finzi et al. 1998a, 1998b; Kizlinksi et al. 2002). Similar patterns of higher C:N ratio have been detected between Eastern Hemlock- vs. Black Birch-dominated plots in western Massachusetts (Ignace et al. 2018). Soils under Eastern Hemlock canopies also tend to have higher exchangeable $\mathrm{Al}$ and $\mathrm{Fe}$ concentrations, and lower levels of exchangeable plant nutrients, like $\mathrm{Ca}$ and $\mathrm{Mg}$, when compared to soils under co-occurring deciduous trees (Finzi et al. 1998b). Overall, the understory environmental conditions and nutrient cycling processes typical of Eastern Hemlock stands are clearly unique and unlikely to be maintained in the northeastern US as these forests are replaced by Black Birch and other deciduous trees. This regional dynamic suggests that a significant homogenization of forest understory environmental conditions is underway.

One of the ecological guilds likely to be directly impacted by major changes in forest composition and soil conditions are bacteria and fungi involved in decomposition and nutrient cycling. Worldwide, the diversity and richness of soil bacterial communities varies by ecosystem, and their diversity is often linked to the dominant plant species' litter characteristics, including its effects on soil $\mathrm{pH}$ and other edaphic conditions (Fierer and Jackson 2006). Changes in litter quality and soil 
$\mathrm{pH}$ are also likely to affect fungal communities and their relative contributions to decomposition processes compared to bacteria. For example, acidic forest soils generally have a high ratio of percent fungal to bacterial respiration (Blagodatskaya and Anderson 1998). These soil fungi are integral to the functioning and health of temperate forest ecosystems (Klein et al. 2016, Simard et al. 1997).

Both saprobic and mycorrhizal fungi species are closely tied to and involved in complicated feedbacks with dominant tree species. For example, there is evidence that mycorrhizal fungal communities differ depending upon the identity of dominant tree species in forest ecosystems (Dickie et al. 2006, Weber et al. 2005). Fruiting body surveys are a useful tool for studying this relationship and have been used to detect evidence of habitat partitioning among epigeous macrofungi. For example, Chen et al. (2018) used such surveys to determine that macrofungal species composition in Chinese forests varies based on microhabitat and is correlated with dominant plant species and characteristics, such as canopy cover and plant density. These patterns also appear to hold for saprobic fungi in some ecosystems; for example, a group of saprobic species, known as brown rot species, are often found exclusively on conifers (Eastwood et al. 2011, Hibbett and Donoghue 2001). While it is clear that forest successional stage (Ishida et al. 2007, Smith et al. 2002), severe die-back (Anderson et al. 2010), and dominant tree type (Dickie et al. 2006, Weber et al. 2005) significantly influence macrofungal communities, few studies have examined how the loss of a foundation tree species and the subsequent transition to a different dominant tree species might affect macrofungal communities.

In this study, we focused on the potential for shifts in fungal and bacterial communities found in the forest floor following removal of Eastern Hemlock from the forest canopy and its replacement by deciduous trees, such as Black Birch. We hypothesized that fungal and bacterial communities are particularly sensitive to changes in Eastern Hemlock abundance, as many species in these communities are directly involved in decomposition processes in the forest floor and may be strongly affected by plant-litter characteristics, such as $\mathrm{C}: \mathrm{N}$ ratio and the presence of secondary compounds, that differ between evergreen and deciduous tree species. To gauge how these community changes might unfold over longer time spans, beyond the initial loss of Eastern Hemlock and associated canopy disturbance, we used an approach involving a space-for-time substitution. At 2 sites in western Massachusetts, we compared spatially paired forest plots with intact, Eastern Hemlock-dominated canopies and adjacent plots where Eastern Hemlock was removed by selective logging in the late 1980s to early 1990s, after which vigorous stands of young Black Birch have grown in their place in the last $\sim 25-30$ years. We used repeated surveys of macrofungi fruiting bodies to characterize dominant fungi in plots, and assays of bacterial colony-forming units (CFUs) in soil organic horizon material to estimate microbial abundance. We predicted that when comparing between Eastern Hemlock- and Black Birch-dominated plots, there would be differences in $(i)$ key physical and chemical characteristics of the forest floor, (ii) the composition and diversity of macrofungal communities, and (iii) the timing and patterns of bacterial abundance as estimated by CFU counts. 


\section{Methods}

\section{Study sites}

The primary study site for this project was Smith College's Ada and Archibald MacLeish Field Station, located in Whately, MA (42 $\left.27^{\prime} 17.9^{\prime \prime} \mathrm{N}, 72^{\circ} 40^{\prime} 55.2^{\prime \prime} \mathrm{W}\right)$ at 270 -m elevation (Fig. 1). The MacLeish Field Station includes 105 ha of mostly secondary forest developed on $19^{\text {th }}$-century pasture land situated in the Northern Hardwoods-Hemlock-White Pine region of the northeastern US (Westveld 1956, Zukswert et al. 2014). Since 2009-2010, HWA and EHS have been observed on Eastern Hemlocks at the site; however, relatively few trees have died due to the pests, and Eastern Hemlock canopies in recent years still appear healthy and include new growth (J. Bellemare, pers. observ.). Cold winters as well as the competitive interaction between HWA and EHS may be slowing the decline of Eastern Hemlock in this region compared to sites further south in the eastern US, where Eastern Hemlock mortality rates due to HWA have been much higher (Orwig and Foster 1998, Preisser and Elkinton 2008, Webster et al. 2012).

At the MacLeish Field Station, we established a series of six $10 \mathrm{~m}$ x $15 \mathrm{~m}$ plots in a matrix forest of intact, 100-year old Hemlock-Northern Hardwoods forest ( $\mathrm{J}$. Bellemare, unpubl. tree core data). This forest area also includes smaller patches

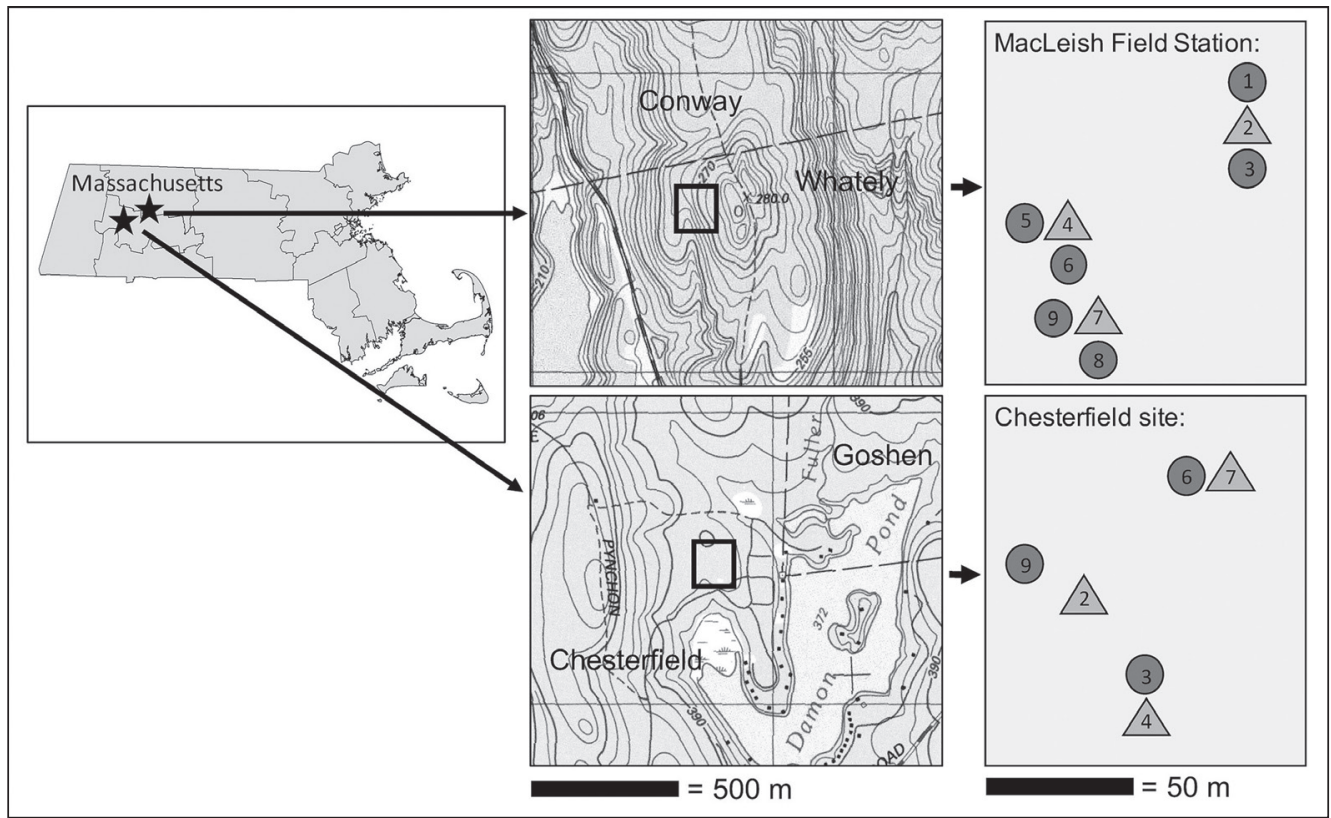

Figure 1. Locations of the 2 study sites in western Massachusetts investigated for this research (contour interval $=5 \mathrm{~m}$ ), including a schematic depicting the relative positions of mature Eastern Hemlock and young Black Birch plots within the study sites. Gray circle = Eastern Hemlock plot; gray triangle $=$ Black Birch plot, with plot number indicated. The numbering system at the Chesterfield site included additional plots that were not included in this study, hence the non-sequential number scheme. At the MacLeish site, only plots 1, $2,4,5,7$, and 8 were included in the soil organic horizon mixed model ANOVAs, while all 9 plots were surveyed for macrofungi and were included in the NMS ordination analysis. 
of young, 25-30-year old Black Birch trees that developed in logging gaps created by selective cutting of Eastern Hemlock and Quercus rubra L. (Red Oak) ca. 1988 (Zukswert et al. 2014). We established a $10 \mathrm{~m} \mathrm{x} 15 \mathrm{~m}$ plot in each of 3 distinct young Black Birch stands and, associated with each of those, 2 adjacent plots in the surrounding, intact Eastern Hemlock forest (within 5-10 m; Fig. 1). Previous studies conducted in these plots have shown that leaf-litter accumulation was modestly, but significantly, greater in the Eastern Hemlock plot areas compared to the Black Birch plots, with the dominant tree species in each plot contributing the largest share of leaf-litter inputs in that plot (Ignace et al. 2018). The Black Birch stands appeared analogous to the dense growth of Black Birch commonly observed to replace Easern Hemlock killed by HWA in southern New England (Ignace et al. 2018, Orwig and Foster 1998, Zukswert et al. 2014). In effect, the 1980s logging activity at this site created an "accidental experiment" (HilleRisLambers et al. 2013) in removal of Eastern Hemlock and has allowed for direct comparison, in a space-for-time substitution framework, between intact Eastern Hemlock forests and the types of Black Birch-dominated forests that typically replace them following HWA-induced mortality in the region (Ignace et al. 2018, Zukswert et al. 2014). Similar experimental approaches have been employed at Harvard Forest in central Massachusetts, using logging and tree girdling to mimic decline of Eastern Hemlocks in advance of actual HWA mortality, allowing simultaneous comparison of intact versus disturbed or declining Eastern Hemlock stands (Ellison et al. 2010, Orwig et al. 2013).

In addition to the 9 study plots at the MacLeish Field Station, we also established a similar series of 6 research plots at a second site in Chesterfield, MA $\left(42^{\circ} 25^{\prime}\right.$ 19.2"N, 72 $50^{\prime} 24^{\prime \prime}$ W; Fig. 1,) where logging in the 1990s had also created patches of young Black Birch forest nested within intact, Eastern Hemlock-dominated stands. Mature Eastern Hemlock trees in the surrounding forest are typically 80-90 years of age (J. Bellemare, unpubl. tree core data). The second site is situated at higher elevation $(\sim 400 \mathrm{~m})$, and has not yet been significantly invaded by HWA or EHS, again allowing for simultaneous comparison of young Black Birch stands to the surrounding mature Eastern Hemlock forest. At this second site, the overall design was similar to the MacLeish Field Station, with three $10 \mathrm{~m} \times 15 \mathrm{~m}$ plots in young Black Birch forest each paired with in this case just a single $10 \mathrm{~m} \times 15 \mathrm{~m}$ plot in the surrounding mature Eastern Hemlock forest (within 5-10 m of each associated birch plot).

\section{Forest composition}

We tallied by species all trees greater than $1.4 \mathrm{~m}$ in height in the $10 \mathrm{~m} \times 15 \mathrm{~m}$ plots and measured them for diameter at breast height (DBH). We recorded the total basal area of each tree and the overall species composition to compare the young Black Birch and mature Eastern Hemlock forest types sampled at the 2 sites. Data on forest composition were tabulated for descriptive purposes only and were not statistically analyzed. 


\section{Soil organic horizon characteristics}

In each research plot, we sampled characteristics of the forest-floor soil organic horizon at 10 random points. At each point, we assessed the thickness of the soil organic horizon and excised and collected a $0.25 \mathrm{~m} \times 0.25 \mathrm{~m}$ sample. We processed these samples (oven-drying [ $75^{\circ} \mathrm{C}$ for $48 \mathrm{~h}$ ], homogenization, and sieving to $<2$ $\mathrm{mm}$ ) and took a subsample of each for chemical analysis of $\% \mathrm{C}, \% \mathrm{~N}$, and $\mathrm{C}: \mathrm{N}$ ratio at the Cornell Stable Isotope Laboratory (Ithaca, NY) using a Thermo Finnigan Delta Plus mass spectrometer connected to a NC2500 elemental analyzer (Carbo Erba Instruments, Milan, Italy) for continuous flow analysis of carbon and nitrogen.

\section{Macrofungal community characterization}

We surveyed for macrofungi fruiting bodies within each plot on an approximately bi-weekly basis in summer and early fall 2014 at the MacLeish Field Station and Chesterfield sites. During summer 2014, the 2 sites were typically surveyed within 1 week of each other. Additional surveys were conducted in 2015. All plots within a site were surveyed on the same day to ensure comparability. In total, we conducted 6 surveys of mature Eastern Hemlock and young Black Birch plots in summer and early fall 2014 at the MacLeish Field Station site, with 2 additional surveys of these plots in summer 2015. At the Chesterfield site, we conducted a total of 6 macrofungi surveys: 5 in summer 2014 and 1 additional survey in summer 2015.

For each macrofungi survey, we located and collected all mature fruiting bodies within the plots, noting the substrate on which they had developed (e.g., mineral soil, soil organic horizon, rotting wood). We documented the morphological characteristics of each collection (e.g., cap color and texture; presence of gills vs. pores; stipe characteristics) and imaged the sample. We also generated spore prints for most samples to document spore color. We then air-dried the specimens at room temperature for long-term preservation and additional identification work in the future. We used the morphological traits documented and substrate information collected to assign each morphologically distinct macrofungi taxon sampled to a species, genus, or broader taxonomic grouping, primarily using Mushrooms and Other Fungi of North America (Phillips 2010) as a reference. We considered spatially clustered fruiting bodies that were morphologically identical to be 1 individual of 1 species. Based on these records, we tabulated the number and abundance of distinct macrofungi taxa for each plot in each survey.

\section{Bacterial abundance: Colony-forming units}

During the summers of 2015 and 2016, we collected 3 sample replicates of organic horizon soil adjacent to the young Black Birch and mature Hemlock plots at the MacLeish Field Station site in order to assess bacterial abundance in soils of the 2 forest types. A 50-mL polypropylene tube was filled with the soil and brought back to the lab. We used a 1-g subsample of the soil for a dilution series in order to estimate bacterial CFUs. In a single gram of soil, there are typically more than $10^{7} \mathrm{CFUs}$, so in order to accurately estimate CFUs, we created a tenfold soil dilution series. First, a 1-g subsample of the original soil was mixed with $9 \mathrm{~g}(\mathrm{~mL})$ of phosphate buffer solution (PBS) yielding a $10^{\circ}$ solution, and then $1 \mathrm{~mL}$ of this 
solution was mixed with an additional $9 \mathrm{~mL}$ of PBS to create a $10^{-1}$ solution; we continued this protocol until reaching the $10^{-5}$ stage dilution, retaining samples at each stage in the dilution process. From each of these dilution steps, $100 \mu \mathrm{L}$ were transferred to an agar plate and allowed to incubate for $1-2$ days at $25{ }^{\circ} \mathrm{C}$. We created the agar plates using a solution of $10 \%$ TSA (tryptic soy agar) content per $1 \mathrm{~L}$ of water, which was then autoclaved for mixing and sterilization. The media was evenly distributed in each petri dish ( $\sim 25 \mathrm{~mL})$ and allowed to solidify, prior to introducing each soil-sample dilution step. We then assessed the number of CFUs visible on each plate and identified the dilution step plate on which the CFU abundance had fallen to within the countable range ( $25-300$ CFUs; Maturin and Peeler 2001, Tomasiewicz et al. 1980). We then precisely counted the CFUs to extrapolate and estimate CFU abundance in the soil organic horizon at the time of collection.

\section{Statistical analyses}

Diagnostic tests indicated that the soil organic horizon thickness and data on the chemical composition of the organic horizon were normally distributed, and we therefore used a mixed model ANOVA to assess differences between the 2 forest types and between the 2 study sites, evaluate the effect of plot, and explore potential site $\mathrm{x}$ forest type interaction effects. The model included site, forest type, and their interaction as fixed effects, and plot as a random effect to account for the 10 soil organic horizon measurements taken per plot (e.g., organic horizon thickness, $\% \mathrm{C}$, $\% \mathrm{~N}$ ). We included these multiple random observations per plot in order to increase the accuracy of our estimates of key soil variables, as we expected there to be considerable small-scale spatial heterogeneity in the forest floor. The inclusion of plot as a random effect in our model accounts statistically for the non-independence of these 10 point samples within each plot and should provide reliable estimates of the fixed effects of interest (i.e., forest type, site, and their interaction).

To ensure a balanced design, we included only 3 of the 6 Hemlock plots (1 from each pair of plots that were associated with each of the 3 Black Birch plots) surveyed at the MacLeish Field Station site in the final ANOVA presented here that tested organic horizon characteristics. The Chesterfield site included only 6 plots total (3 Hemlock vs. 3 young Black Birch) so it did not raise an issue of balance. To confirm that the choice of which 3 Hemlock plots from MacLeish were sampled did not qualitatively change our results, we conducted a parallel set of ANOVAs using data from these 3 plots. We used Tukey's honestly significant difference (HSD) post-hoc comparisons to assess pairwise differences in organic horizon characteristics between and within sites.

For the macrofungi fruiting body survey data, we analyzed morphospecies richness with a series of paired student's $t$-tests for each survey event where both study sites were sampled within 1 week of each other ( $n=5$ events). Specifically, spatially adjacent plots from the 2 forest types (Black Birch and Eastern Hemlock) were treated as pairs in these tests, taking advantage of the stratified alternating pattern of forest types at the study sites (see Fig. 1). The paired $t$-tests approach also had the advantage of directly comparing plots that were most similar in terms of underlying 
soils, slope, and aspect due to their proximity but differed in forest canopy type. Data from survey dates that did not fall within a week of each other at both sites were excluded from these tests ( $n=3$ surveys at MacLeish site, 1 survey at Chesterfield site). To assess overall differences in fungi richness between the 2 forest types, we ran a second paired $t$-test on the total morphospecies count for each plot, across all survey dates, including both sites. The extra MacLeish Eastern Hemlock plots described above were excluded from this total morphospecies analysis as well in order to preserve the paired and balanced data structure. We used a Bonferroni correction for multiple tests to account for the numerous $t$-tests $(n=6)$. We used ANOVA to compare Bacterial CFU counts between the Black Birch and Eastern Hemlock plots at the MacLeish Field Station over the course of the 2015-2016 sampling period. We conducted these analyses using the 'nlme' (Pinheiro et al. 2018) and 'stats' packages in R version 3.3.3 (R Core Team 2013).

In addition to the analyses of fungi morphospecies richness described above, we also explored overall variation in the morphospecies composition of the macrofungal communities in Eastern Hemlock versus Black Birch forest plots using non-metric multidimensional scaling (NMS) in PC-ORD (Version 7.02; McCune and Grace 2002). For this multivariate analysis, the total set of distinct macrofungi morphospecies detected in each plot across all surveys was compiled and treated as the overall community sample for that plot. This data set was "conservative" in that we grouped morphologically similar samples from different survey dates into single species or taxa categories, avoiding potential overestimation of total richness and composition. We converted these data to a simple presence/absence matrix for each taxon. For this NMS analysis, we used Sorensen distance measure with PC-ORD's default NMS “slow and thorough" settings (McCune and Grace 2002). These settings generate a random seed and include 250 runs of real data and 250 runs of randomized data. We used mean plot organic horizon thickness and $\mathrm{C}: \mathrm{N}$ ratio to create a secondary environmental data matrix to explore correlations (Pearsons $r^{2}$ generated in PC-ORD) between communities and the organic horizon characteristics. The NMS also allowed us to evaluate the overall similarity or differentiation of fungal communities observed in the plots, as well as assess differences associated with forest type (mature Eastern Hemlock vs. young Black Birch) and site (MacLeish Field Station vs. Chesterfield).

\section{Results}

\section{Forest composition}

The young Black Birch plots established at the MacLeish Field Station and Chesterfield study sites following logging in the late 1980s to early 1990s were similar in composition, with Black Birch being the most abundant tree forming the new canopy over the former logging gaps (Table 1). Of the total basal area in the Black Birch plots, Black Birch comprised 83\% at the MacLeish Field Station site and 75\% at the Chesterfield site. Other species in these plots were deciduous trees, including Betula alleghaniensis Britt. (Yellow Birch), Acer rubrum L. (Red Maple), and occasional Fagus grandifolia Ehrh. (American Beech); Eastern Hemlock had not 
recruited in these young forest areas at that time. These plots still exhibited relatively low total basal area compared to the surrounding, mature forest (e.g., 27-35\% of that seen in adjacent mature plots; Table 1).

In the adjacent mature Eastern Hemlock forest plots, Eastern Hemlock was the most abundant canopy tree species at the MacLeish Field Station and Chesterfield sites, comprising $\sim 58 \%$ and $\sim 60 \%$ of tree basal area in these stands, respectively (Table 1). These mature Eastern Hemlock forests also included a lesser component of deciduous trees, including Red Maple, Black Birch, and Yellow Birch, among others. Evergreen conifers, including Pinus strobus L. (White Pine) and Picea rubens Sarg. (Red Spruce) were occasional, the latter only present in 1 plot at the Chesterfield site.

\section{Soil organic horizon characteristics}

The soil organic horizon was significantly thicker in mature Eastern Hemlock forest plots compared to young Black Birch plots (ANOVA forest type effect: $F_{8,108}=$ 108.9, $P<0.001$; Fig. 2). At the MacLeish Field Station site, the organic horizon was on average $2.5 \mathrm{~cm}( \pm 0.2 \mathrm{SE})$ thick in Black Birch plots and $4.1 \mathrm{~cm}( \pm 0.1 \mathrm{SE})$

Table 1. Tree species composition and basal area $\left(\mathrm{m}^{2} / \mathrm{ha}\right)$ at the MacLeish Field Station and Chesterfield study sites in western Massachusetts. All living trees $>1.4 \mathrm{~m}$ in height were included in the tally of total basal area. Species \% values are averages across multiple plots of a forest type at a site and do not sum to exactly $100 \%$. Data are presented for descriptive purposes only and were not analyzed statistically. Dashes indicate a species was not present in a given plot type.

\begin{tabular}{lcc} 
Tree species by site & $\begin{array}{c}\text { Young Black Birch } \\
\text { plots (mean \% of } \\
\text { total basal area } \pm \text { SE) }\end{array}$ & $\begin{array}{c}\text { Mature Eastern Hemlock } \\
\text { plots (mean \% of } \\
\text { total basal area } \pm \text { SE) }\end{array}$ \\
\hline MacLeish & - & $0.6 \pm 0.5$ \\
American Beech & $83.4 \pm 3.6$ & $27.3 \pm 7.2$ \\
Black Birch & $2.2 \pm 2.1$ & - \\
Prunus serotina Ehrh (Black Cherry) & - & $57.7 \pm 5.6$ \\
Eastern Hemlock & $0.1 \pm 0.1$ & - \\
Ostrya virginiana (Mill.) K. Koch (Hop Hornbeam) & $3.3 \pm 2.0$ & $0.1 \pm 0.1$ \\
Betula papyrifera Marshall (Paper Birch) & $3.6 \pm 3.4$ & $4.9 \pm 1.7$ \\
Red Maple & $3.8 \pm 3.8$ & $1.4 \pm 1.4$ \\
Red Oak & - & $0.1 \pm 0.1$ \\
Sassafras albidum $($ Nutt.) Nees (Sassafras) & - & $0.8 \pm 0.8$ \\
Sugar Maple & - & $6.3 \pm 6.3$ \\
White Pine & $3.7 \pm 2.7$ & $1.4 \pm 1.4$ \\
Yellow Birch & $14.1 \pm 1.8$ & $51.7 \pm 5.7$ \\
Mean total basal area $\left(\mathrm{m}^{2} / \mathrm{ha}\right) \pm$ SE: & & \\
Chesterfield & $1.3 \pm 1.3$ & $0.1 \pm 0.1$ \\
American Beech & $75.4 \pm 4.9$ & $0.5 \pm 0.5$ \\
Black Birch & - & $59.6 \pm 9.0$ \\
Eastern Hemlock & $7.4 \pm 7.4$ & $23.4 \pm 10.3$ \\
Red Maple & - & $11.2 \pm 11.2$ \\
Red Spruce & $17.2 \pm 9.2$ & $5.3 \pm 5.3$ \\
Yellow Birch & $15.9 \pm 1.6$ & $45.3 \pm 5.6$ \\
Mean total basal area $\left(\mathrm{m}^{2} / \mathrm{ha}\right) \pm$ SE: & & \\
\hline
\end{tabular}


in Eastern Hemlock plots, about 1.6 times thicker in the latter (Tukey's HSD: $P=$ $0.028)$. At the Chesterfield site, the mean organic horizon thickness was $1.4 \mathrm{~cm}( \pm$ $0.1 \mathrm{SE})$ in Black Birch plots and $6.9 \mathrm{~cm}( \pm 0.4)$ in Eastern Hemlock plots, a 4.9-fold difference (Tukey's HSD: $P<0.001$ ). The ANOVA also detected a nearly significant site effect $\left(F_{8,108}=4.5, P=0.066\right)$, and a significant site $\mathrm{x}$ forest type interaction $\left(F_{8,108}=28.4, P=0.001\right)$, reflecting the greater difference in the thickness of the organic layer in Black Birch versus Eastern Hemlock plot organic horizons at the Chesterfield site, compared to the MacLeish site.

In parallel to the physical differences in soil organic horizon structure between mature Eastern Hemlock and young Black Birch plots, we also found significant differences in the chemical composition of the organic horizon. For example, the organic horizon of Eastern Hemlock forest plots had significantly higher percent carbon per unit mass compared to Black Birch soil organic horizons overall (ANOVA: $F_{8,108}=9.6, P=0.02$ ); this difference was strong at the Chesterfield site (Tukey's HSD: $P=0.022)$ but not significant within the MacLeish site $(P=0.94$; Fig. 3a). The nitrogen content (\%) of organic horizons did not differ significantly or consistently between forest types $\left(F_{8,108}=0.04, P=0.88\right)$ but did differ between sites $\left(F_{8,108}=7.5, P=0.026\right)$. The significant difference in nitrogen content $(\%)$ between sites was largely driven by differences between the Eastern Hemlock plots at Chesterfield compared to those at MacLeish (Tukey's HSD: $P=0.038$; Fig. 3b). However, the more biologically meaningful C:N ratio differed strongly between forest types, with $\mathrm{C}: \mathrm{N}$ ratio being significantly higher in Eastern Hemlock forest organic horizons $\left(F_{8,108}=19.591, P<0.0022\right)$. The soil C:N ratio for the Eastern Hemlock plots averaged $26.7( \pm 0.50 \mathrm{SE})$ at the Chesterfield site and $26.5( \pm 0.40 \mathrm{SE})$ at MacLeish; in contrast, the C:N ratio for the Black Birch plots was $21.9( \pm 0.61 \mathrm{SE})$ at Chesterfield and $23.5( \pm 0.34 \mathrm{SE})$ at the MacLeish Field Station site (Fig. 3c). The contrast in C:N ratio between forest types within sites

Figure 2. Thickness of the soil organic horizon in mature Eastern Hemlock and young Black Birch forest type plots at the MacLeish Field Station and Chesterfield study sites. Letters designate pairs that are significantly different based on Tukey's HSD post-hoc comparison. Error bars are \pm 1 standard error.

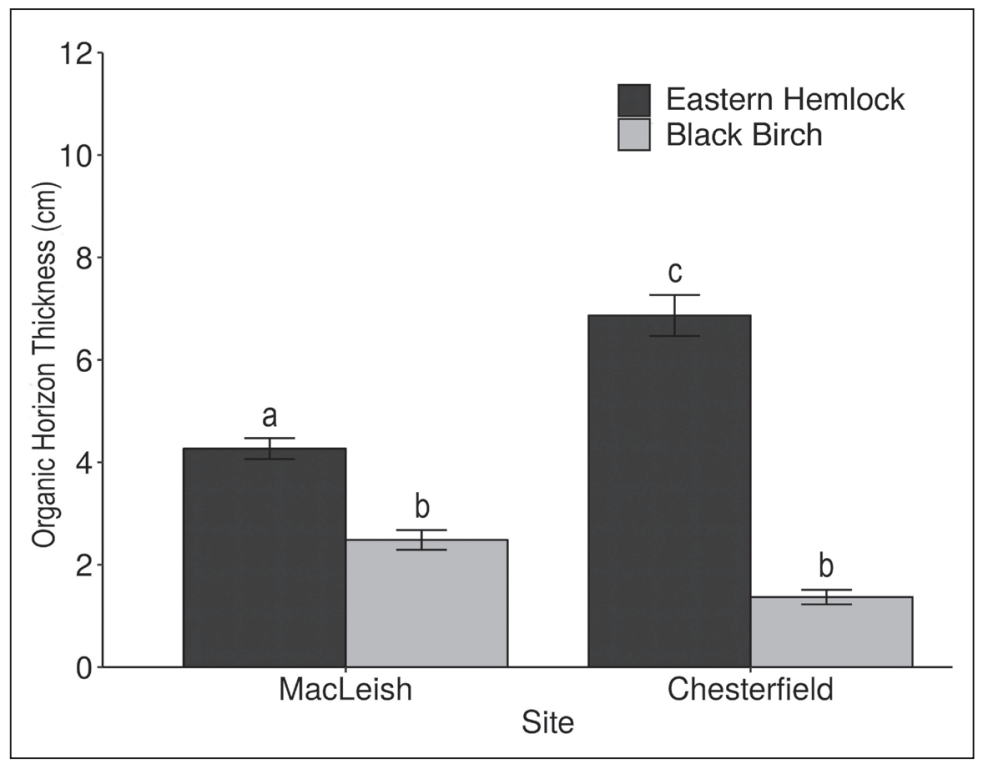


was significant at Chesterfield (Tukey's HSD: $P=0.019$ ) but not at the MacLeish site $(P=0.17)$.

\section{Macrofungal community characterization}

We collected a total of 748 macrofungi fruiting body samples from the plots over the course of the 2014-2015 surveys. These collections were sorted, identified, and assigned to 109 distinct macrofungi taxa (Appendix 1). Total abundance of fruiting bodies in surveys varied from $n=10$ to $n=117$ per site per survey. The survey with the highest abundance of fruiting bodies and highest mean number of morphospecies per plot was the Chesterfield 17 July 2015 survey, with 117 fruiting bodies collected across the 6 plots at the site, and a mean of 12.8 morphospecies $( \pm$ 0.4 SE) per plot (Fig. 4).

The Eastern Hemlock and Black Birch forest types did not differ significantly in the mean number of macrofungi taxa recorded per plot at either site, at any survey date in 2014 or 2015 (all individual paired $t$-tests: $P>0.05$; Fig. 4). The mean total number of morphospecies collected in Eastern Hemlock and Black Birch plots over all survey dates, at both sites, was also not significantly different (paired $t$ test: $P>0.05)$. Across the 5 survey dates analyzed, the number of morphospecies found at the Chesterfield site averaged 3.2 morphospecies $( \pm 1.6 \mathrm{SE})$ in Eastern Hemlock plots and $4.7( \pm 2.6 \mathrm{SE})$ in Black Birch plots. Similarly, the mean number

Figure 3. Carbon and nitrogen content $(\%)$ and $\mathrm{C}: \mathrm{N}$ ratio of soil organic horizons in mature Eastern Hemlock versus young Black Birch forest type plots at the MacLeish Field Station and Chesterfield study sites. Letters designate pairs that are significantly different based on Tukey's HSD post-hoc comparison. Error bars are \pm 1 standard error.

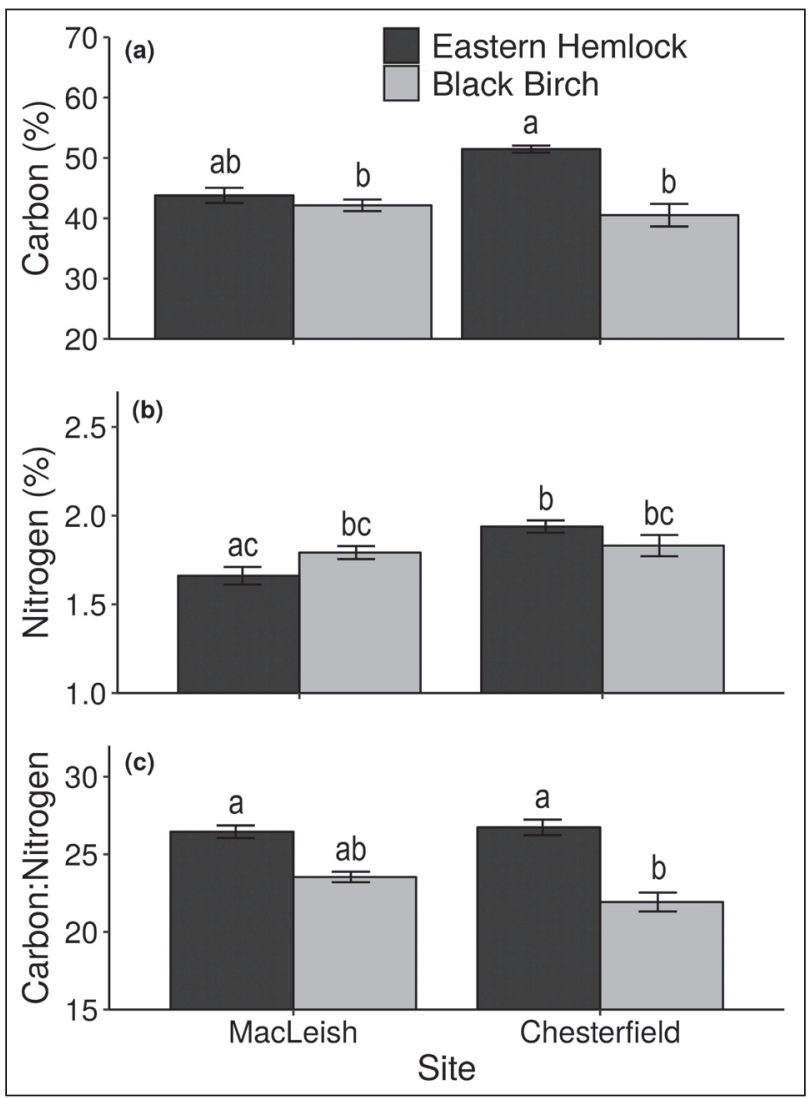


of macrofungi morphospecies detected at the MacLeish Field Station site was comparable, and statistically indistinguishable, between the Eastern Hemlock and Black Birch plots (mean $=4.4 \pm 2.3 \mathrm{SE}$ and $3.8 \pm 1.9 \mathrm{SE}$, respectively).

Of the 109 distinct macrofungi taxa identified from the Eastern Hemlock and Black Birch forest types (Appendix 1), 40 taxa (36.6\% of total) were observed only in Eastern Hemlock plots, and an additional 11 taxa were associated with this forest type ( $>60 \%$ occurrence in the forest type; Fig. 5; Appendix 1). Among the taxa with a close association with Eastern Hemlock plots, Cortinarius armillatus (Fr.) Fr. stood out as being collected multiple times (23 fruiting bodies) and almost exclusively in Eastern Hemlock plots (96\% of collections). In contrast, 31 macrofungi taxa (28.4\% of total) were collected only in the Black Birch plots, and an additional 18 taxa were associated with this forest type ( $>60 \%$ of occurrences). For example, Leotia viscosa Fr. was collected only in Black Birch plots (3 collections), and Lactarius gerardii $\mathrm{Pk}$. was fairly common (13 collections total) and positively associated with Black Birch plots (69\% of collections). Finally, some macrofungi taxa appeared to be generalists relative to forest type and were commonly collected in both habitats (e.g., Russula brevipes $\mathrm{Pk}$. and Pseudoarmillariella ectypoides Peck (Singer); Appendix 1). Overall, only 9 macrofungi taxa (8\%) exhibited abundance patterns more or less evenly divided between the 2 forest types $(40-60 \%$ in

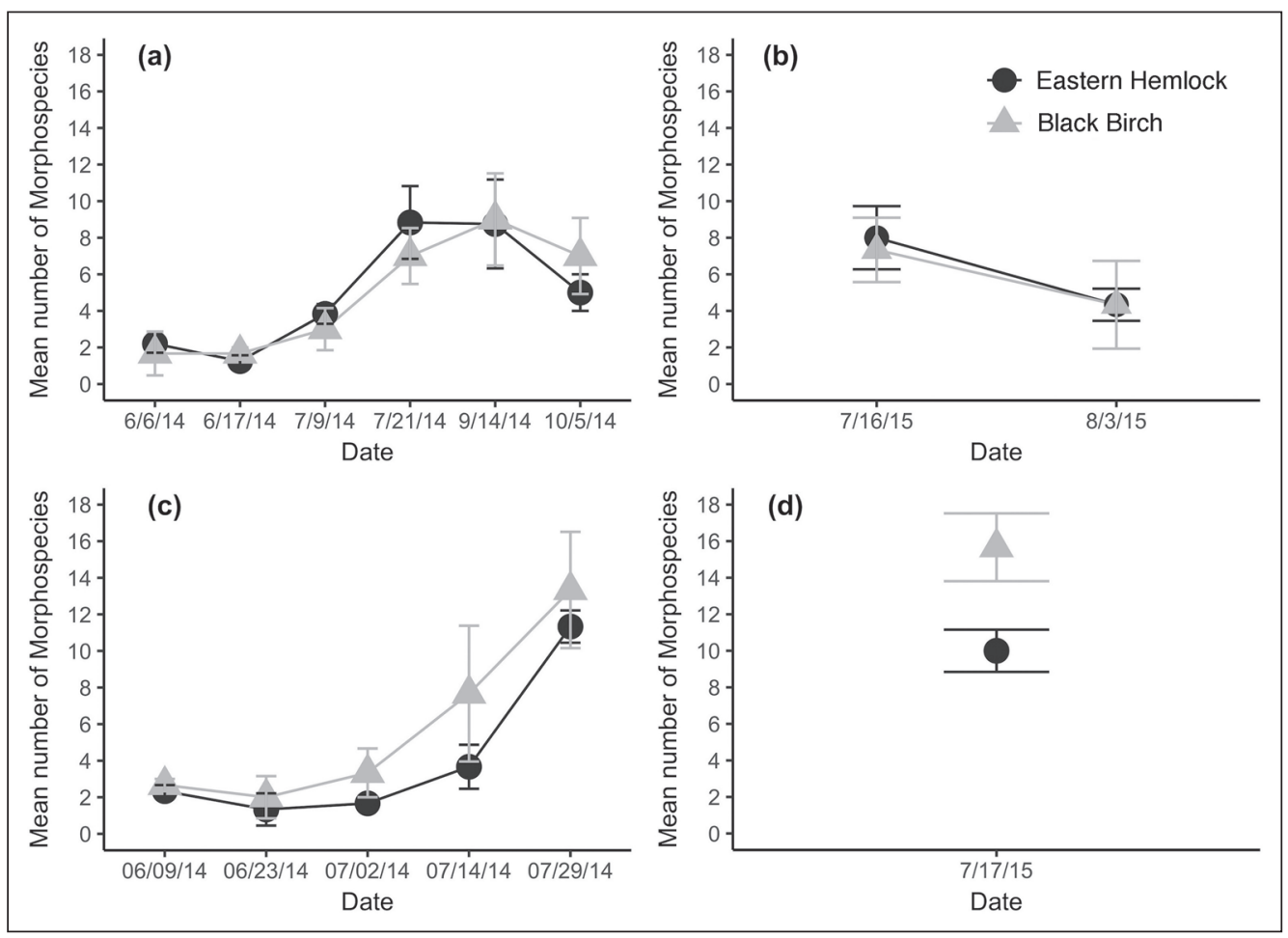

Figure 4. Richness of macrofungi morphospecies detected as fruiting bodies across multiple surveys in spatially paired mature Eastern Hemlock and young Black Birch plots at (a and b) MacLeish Field Station and (c and d) Chesterfield. 
each forest type; Appendix 1). The remaining 100 taxa (92\%) showed patterns of weak to strong association with one forest type or the other. More strikingly, of the 109 taxa identified from the Eastern Hemlock and Black Birch plots, the rare taxa,

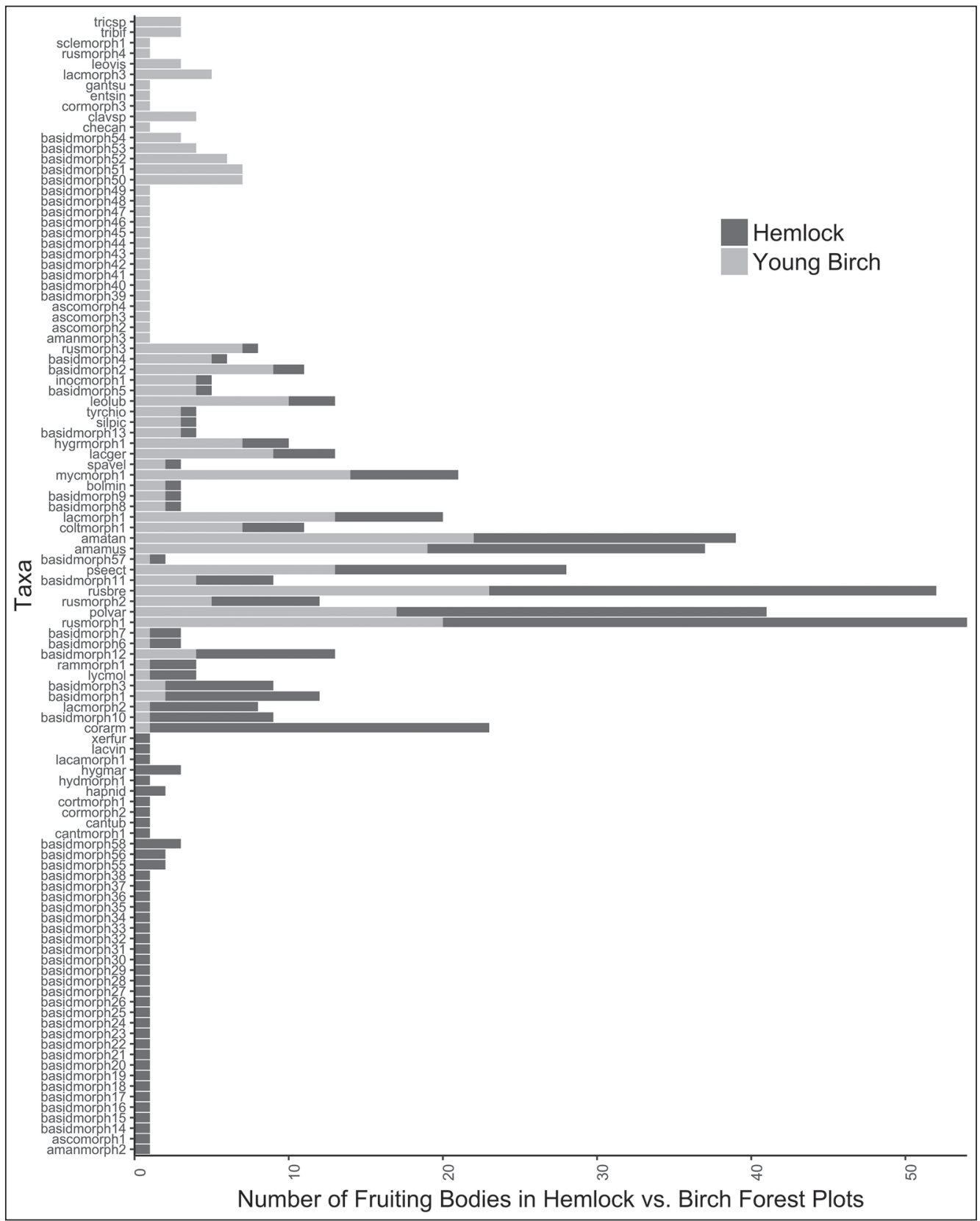

Figure 5. Abundance and habitat associations of 109 macrofungi taxa detected as fruiting bodies in plot surveys from 2014-2015. Taxa are ranked along the $y$-axis by their proportional strength of association with mature Eastern Hemlock vs. young Black Birch plots, based on number of fruiting bodies collected per forest type. Data are compiled from across the 2 study sites. 
defined as taxa collected only once across all surveys $(n=56)$, were more likely to be found in Eastern Hemlock plots $(62.5 \%$ of rare taxa vs. $37.5 \%$, respectively; Fig. 5, Appendix 1).

The NMS analysis of macrofungi presence/absence data suggested that the first 2 ordination axes captured much of the variation present in fungi communities sampled in mature Eastern Hemlock and young Black Birch forest plots (Fig. 6). The coefficients of determination for the correlations between ordination distances and distances in the original $n$-dimensional space were strong for both NMS axis 1 and axis $2\left(R^{2}=0.461\right.$ and 0.227 , respectively), indicating that a high proportion of variation in the community data was represented in the analysis by those axes. Overall, the model was assessed to be a good fit for the data and had a final stress of 17.71 on a 2-dimensional solution after 60 iterations (McCune and Grace 2002). A Monte Carlo test indicated that there was low probability of obtaining a similar level of stress due to chance (axis 1: $P=0.004$, axis 2: $P=0.0359$ ).

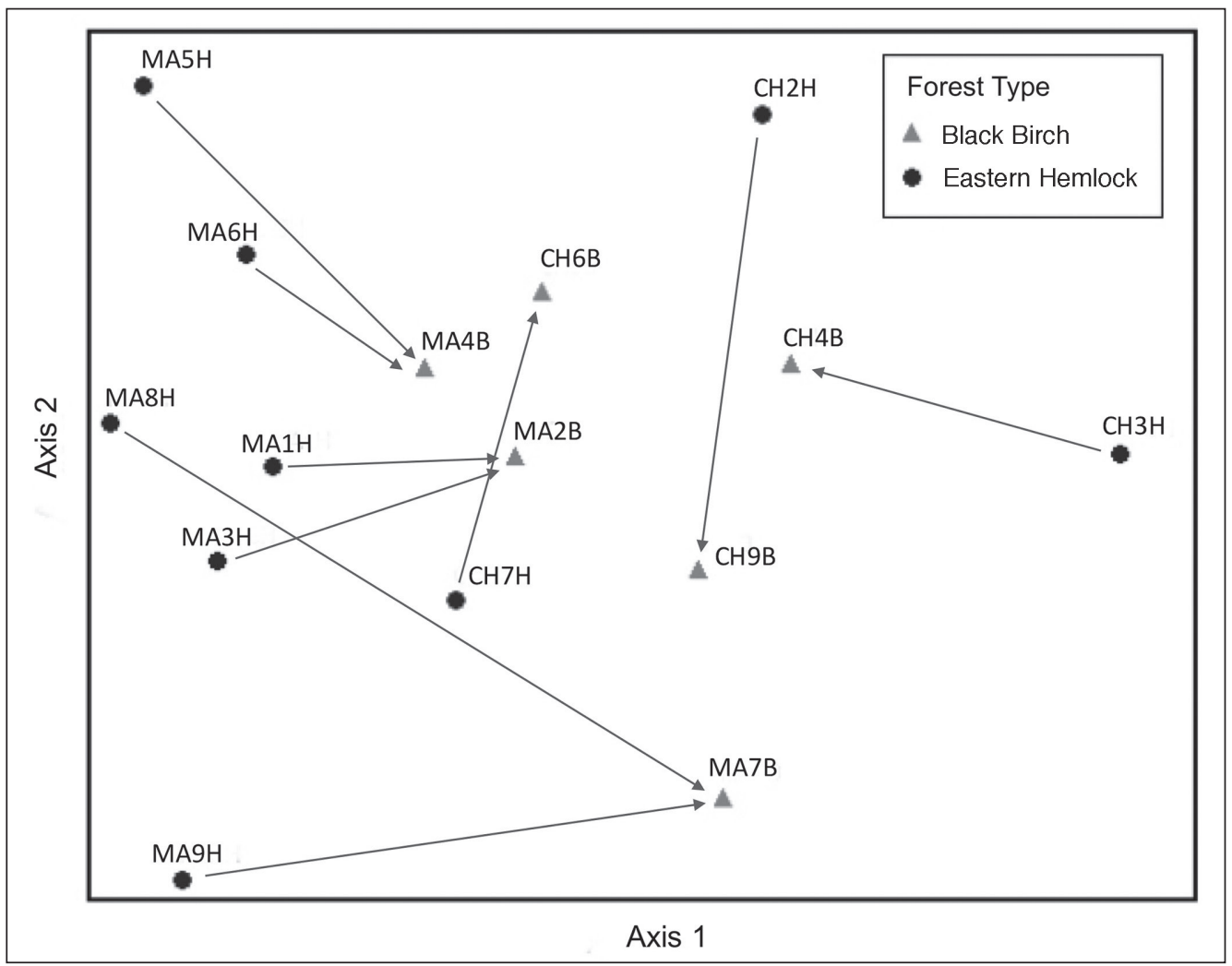

Figure 6. Nonmetric multidimensional scaling (NMS) ordination of macrofungi community data from 9 mature Eastern Hemlock and 6 young Black Birch forest plots at the 2 study sites. Plots are labelled with 4-part alphanumeric codes starting with study site (MA = MacLeish, $\mathrm{CH}=$ Chesterfield $)$, plot number within site, and forest type $(\mathrm{H}=$ Eastern Hemlock, $\mathrm{B}=$ Black Birch). Spatially adjacent plot pairs with different canopy type are connected by arrows. These arrows depict the relative hypothesized "shift" in macrofungi community composition between mature Eastern Hemlock and young Black Birch plots. 
In terms of overall patterns in macrofungal community composition suggested by the NMS results, mature Eastern Hemlock plots were more variable and distinctive in their composition compared to the young Black Birch plots. For example, along both axis 1 and axis 2 of the ordination, Eastern Hemlock plots occupy both the highest and lowest values observed, representing a greater range in compositional variation (Fig. 6). This pattern was driven in part by compositional distinctiveness between Eastern Hemlock plots at the Chesterfield versus MacLeish Field Station sites, which did not overlap along axis 1 of the ordination (Fig. 6). In addition, the greater variability and distinctiveness of Eastern Hemlock plots was driven in part by the higher number of "rare" species unique to individual Eastern Hemlock plots compared to Black Birch plots. In contrast, the macrofungal communities observed in the 6 Black Birch plots were more similar in composition and tended to cluster and overlap near the mid-range of the NMS ordination space described by axis 1 . This pattern suggests that the macrofungi composition displays a higher level of compositional overlap among the Black Birch plots, and includes more common, generalized macrofungi taxa (i.e., fewer rare taxa).

In terms of soil organic horizon characteristics that might influence macrofungal community composition, the NMS results indicated that the plot-level soil organic horizon $\mathrm{C}: \mathrm{N}$ ratio was negatively correlated with axis $1(r=-0.290)$, and more strongly positively correlated with axis $2(r=0.328)$. This result suggests that the soil organic horizon $\mathrm{C}: \mathrm{N}$ ratios might be associated with variation in the macrofungal communities surveyed. Organic horizon thickness was only weakly correlated with axis $1(r=0.016)$ but more strongly negatively correlated with axis $2(r=-0.219)$. Notably, the strength of these relationships with soil organic horizon factors were countered by the distinctiveness of the macrofungal communities of the Eastern Hemlock plots at Chesterfield versus MacLeish Field Station, despite the overall environmental similarity of those plots (e.g., deeper organic horizons, higher $\mathrm{C}: \mathrm{N}$ ratios).

\section{Bacterial abundance: Colony-forming units}

Bacterial CFU counts from the organic horizon soil samples at the MacLeish Field Station site generally followed a seasonal trend in abundance across the 2015 and 2016 growing seasons, with mature Eastern Hemlock plots tending to show higher CFU counts in the growing season (June and July), while young Black Birch plots had significantly higher CFU counts in the fall (Fig. 7). This dynamic was associated with a significant forest type $\mathrm{x}$ survey date interaction in both years (ANOVA: $P<0.001)$. Forest type was also significant in $2015(P<0.001)$, but due in part to this reversal in the abundance of CFUs between forest types between seasons ( summer vs. fall), forest type was not significant in 2016.

\section{Discussion}

The results of this study document substantial changes in the forest floor environment of mature Eastern Hemlock-dominated forest versus young Black Birch-dominated stands, including significantly thicker soil organic horizons, 
and a higher $\mathrm{C}: \mathrm{N}$ ratio of organic material in Eastern Hemlock forests. These patterns are consistent with prior studies suggesting that Eastern Hemlock leaf litter decomposes more slowly than the litter of co-occurring deciduous trees (Cobb 2010, Finzi et al. 2014), and that stands in the northeastern US dominated by Eastern Hemlock have reduced soil respiration and greater carbon stores compared to those dominated by deciduous trees (Finzi et al. 1998a, Ignace et al. 2018, Zukswert et al. 2014). These distinct soil conditions under Eastern Hemlock versus deciduous forest stands are likely to directly influence the guild of forest-floor decomposers, including numerous macrofungi and bacteria. Our results suggest removal of Eastern Hemlock precipitates shifts in the composition, and potential homogenization of, the macrofungal communities associated with these forest plots, and thus are consistent with this expectation. The abundance of CFUs in organic horizon soil samples also suggest differences in the seasonal patterns of activity of microbes in these contrasting forest types, with Eastern Hemlock plots harboring greater CFU abundance in summer, while Black Birch plots showed higher abundance in the fall, when new leaf litter and nutrients are entering the forest-floor system. Overall, these findings document differences in forest-floor fungal and microbial

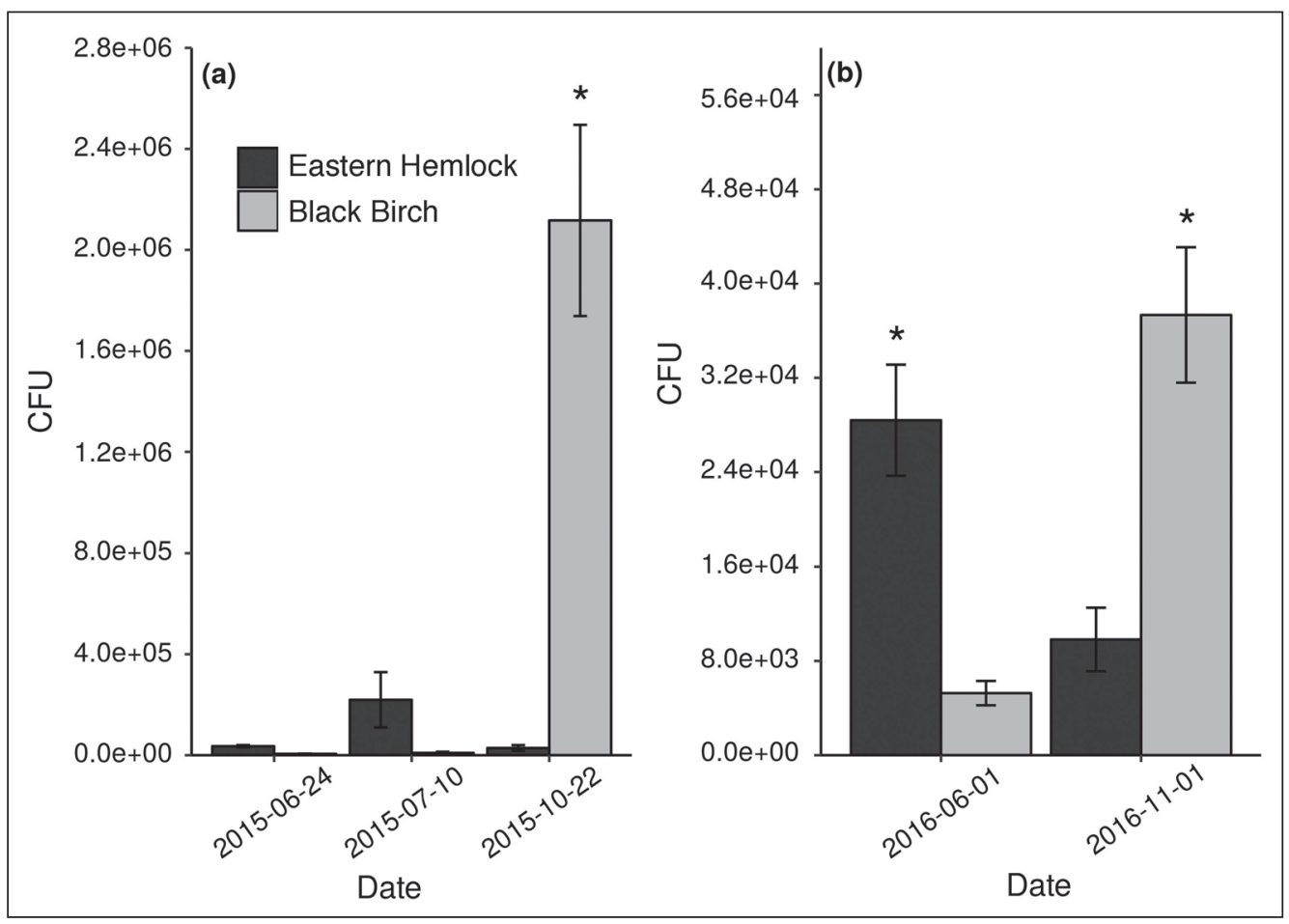

Figure 7. Density of bacterial colony-forming units (CFU) estimated from soil organic horizon samples collected in mature Eastern Hemlock versus young Black Birch plots at the MacLeish Field Station site in summer and fall of (a) 2015 and (b) 2016. In 2015, an ANOVA detected a significant difference between forest types, date of survey, and their interaction (all $P<0.001$ ). In 2016, an ANOVA detected a significant forest type $\mathrm{x}$ date interaction $(P=0.0002)$. Asterisks denote significant differences in CFU between forest types on a given sampling date. 
communities that are likely to develop more broadly across the northeastern US landscape as Eastern Hemlock declines due to exotic insect pests in coming years.

\section{Soil organic horizon characteristics}

The thicker soil organic horizons and the higher $\mathrm{C}: \mathrm{N}$ ratios of soil organic material in the Eastern Hemlock plots sampled likely traces in part to differences in the chemical composition of Eastern Hemlock versus Black Birch leaf litter. For example, the significantly higher $\mathrm{C}: \mathrm{N}$ ratio and lower $\% \mathrm{~N}$ of Eastern Hemlock needles compared to Black Birch leaves likely slows their decomposition by fungal and bacterial decomposers (Cobb 2010, Ignace et al. 2018). In addition, secondary plant metabolites like tannins, which are abundant in evergreens like Eastern Hemlock, can be toxic to microbial communities, can complex or deactivate decomposer enzymes, can form secondary organic compounds resistant to further decomposition, and can decrease rates of $\mathrm{N}$ mineralization (Kraus et al. 2003, Talbot and Finzi 2008). In contrast, the lower C:N ratio of Black Birch leaf litter appears to accelerate decomposition and enhances carbon cycling and soil respiration from the forest floor, resulting in diminished organic horizon development (Cobb 2010, Ignace et al. 2018). Tukey's HSD post-hoc comparisons showed that while the MacLeish site contributed to the overall trend detected in the ANOVA results, $\% \mathrm{C}$ and $\mathrm{C}: \mathrm{N}$ ratio differences between the 2 forest types were greater at Chesterfield, but not significant in post-hoc comparisons at MacLeish. However, given the clear underlying differences at MacLeish (i.e., Hemlock plot $\mathrm{C}: \mathrm{N}$ ratio of $26.5 \pm 0.40$ vs. Black Birch $23.5 \pm 0.34$ ), the trend toward higher $\% \mathrm{C}$ and $\mathrm{C}: \mathrm{N}$ ratio in the soil organic horizons of Eastern Hemlock vs. Black Birch forest plots remains strong. These striking differences in organic horizon composition and nutrient dynamics between Eastern Hemlock- versus Black Birch-dominated forest stands are highly relevant to the ecological niches of many decomposer taxa in the forest floor.

Differences in organic horizon characteristics were also evident between the 2 study sites, including substantially thicker organic horizon development under Eastern Hemlock stands at the Chesterfield site. We suspect that these differences between Eastern Hemlock stands might be due to climatic differences associated with elevation. Conditions are likely cooler and moister at the higher elevation Chesterfield site ( $\sim 400 \mathrm{~m}$ vs. $\sim 270 \mathrm{~m}$ at MacLeish site). Globally, precipitation is positively correlated with total soil organic carbon content (Davidson et al. 2000, Jobbágy and Jackson 2000, Post et al. 1982), and temperature is negatively correlated with soil carbon content (Davidson et al. 2000, Post et al. 1982).

One caveat to our results on $\mathrm{C}: \mathrm{N}$ ratio of soil organic horizon samples is that our samples were oven-dried at a temperature slightly above that recommended by Robertson et al. (1999): $75^{\circ} \mathrm{C}$ vs. $70^{\circ} \mathrm{C}$. However, we do not believe this substantially affected the results (e.g., via volatilization of $\mathrm{N}$ ), as our $\mathrm{C}: \mathrm{N}$ ratio values for Eastern Hemlock organic horizon soils are quite comparable to values recorded from similar forests in the region by Orwig et al. 2008 (22.2 \pm 0.1 to $28.4 \pm 0.1)$. 


\section{Macrofungal community characterization}

Our use of repeated surveys to document the community composition of epigeous macrofungi in the forest plots sampled should provide a reliable indicator of general trends in the abundance and reproductive activity of major taxa active at the sites during the study. There are important caveats to note, such as the lack of inclusion of hypogeous species, the possibility of cryptic morphospecies, and the fact that many species may not fruit every year. However, similar surveys of epigeous macrofungi fruiting bodies have proven to be effective tools for assessing nutrient and disturbance dynamics in forest ecosystems and the associated changes in macrofungal communities (Kranabetter et al. 2009, Tóth and Barta 2010) as well as for detecting the roles dominant plant species and microhabitat might play in structuring macrofungal communities (Chen et al. 2018). In our surveys, we found no evidence of significant overall differences in plot-level morphospecies richness of macrofungi between Eastern Hemlock versus young Black Birch plots (i.e., pairwise $t$-tests failed to detect significant differences in richness at survey dates or in total plot-level richness across all dates). However, a more holistic, non-parametric approach to analyzing compositional shifts using NMS analysis did show some striking differences in macrofungal community structure. Specifically, we found that communities of macrofungi in Eastern Hemlock forests at the 2 sites were distinct from the community samples in Black Birch stands, and were also strongly differentiated in composition among each other (i.e., MacLeish Eastern Hemlock versus Chesterfield Eastern Hemlock plots along NMS axis 1). This finding indicates substantial heterogeneity and distinctiveness in the macrofungal communities of the Eastern Hemlock plots within and between the 2 study sites, while the macrofungal communities emerging in the Black Birch plots were not strongly differentiated between the 2 study sites and were comprised of a more generalized set of common macrofungi taxa. These patterns suggest a trend toward biotic homogenization as forest stands shift from mature Eastern Hemlock- to young Black Birch-dominated canopies.

The reasons that fungal communities change as forest composition shifts from Eastern Hemlock- to Black Birch-dominance are likely related to both host specificity and environmental factors (Eastwood et al. 2011, Hibbett and Donoghue 2001, Ishida et al. 2007, Smith et al. 2009, Tyler 1992). In general, other studies have shown a correlation between the soil chemical environment and fungal community structure. For example, Lilleskov et al. (2002) found a strong negative linear relationship between organic horizon nitrate, foliar nutrients, and fungi species richness. In our study, the NMS analysis showed a relatively strong correlation between soil organic horizon $\mathrm{C}: \mathrm{N}$ ratio and community variation along axes 1 and 2 of the ordination. This result suggests that the community distribution is at least partially associated with organic horizon carbon and nutrient characteristics (e.g., accessibility and rates of $\mathrm{N}$ cycling). Similarly, extractable ammonium $\left(\mathrm{NH}_{4}\right)$ has been found to be correlated with $22.4 \%$ of the variation in EMF fungal communities along a nutrient gradient in a Swedish Boreal forest, and a significant species-environment correlation for soil extractable ammonium was also observed (Toljander 
et al. 2006). The C:N ratio accounted for $19 \%$ of the variation in that fungal community (Toljander et al. 2006). This finding suggests that nitrogen availability and the $\mathrm{C}: \mathrm{N}$ ratio influence the structure of EMF communities, an effect that may be relevant to the present study given the higher $\mathrm{N}$ content of the Black Birch leaf litter (Cobb 2010) and the significantly lower $\mathrm{C}: \mathrm{N}$ ratio of the organic horizon in our Black Birch forest plots.

It is also likely that specialized relationships between some fungi and particular tree species could influence the distribution patterns of those fungi and their associations with mature Eastern Hemlock versus young Black Birch forests. For example, in our study, high percentages of fungi were found exclusively in one forest type or the other (Fig. 5), a pattern consistent with studies suggesting that many ectomycorrhizal fungi exhibit a strong preference in host tree species (Ishida et al. 2007, Smith et al. 2009, Tyler 1992). In contrast, less research has been conducted on the association between saprobic fungi and specific plant species; however, one of the clearest associations between saprobic species and plants is the link between conifers and brown rot-causing saprobic fungi that specialize on decomposing their wood (Eastwood et al. 2011, Hibbett and Donoghue 2001). Some saprobic, wooddecaying taxa, including an unidentified polypore morphospecies, showed host exclusivity and recurrence in this study (Fig. 5). Future work in this system should seek to use molecular tools and environmental DNA sampling to more precisely identify the fungal taxa present, and to document their small-scale distribution patterns and host associations.

\section{Biotic homogenization}

Evidence of biotic homogenization in forest communities due to human disturbance, exotic species, and other environmental change is increasing. For example, a meta-analysis including data from 11 forests in North America and Europe found that secondary forests developing on former agricultural fields generally had lower beta diversity of forest plants compared to undisturbed primary forests (Vellend et al. 2007). Similarly, in response to invasive plants that alter the soil chemical environment, a reduction in fungi community beta diversity has been observed across a representative sample of temperate deciduous forest sites in the northeastern US (Anthony et al. 2017). Comparable patterns of homogenization have been detected in soil bacterial communities following disturbance and conversion to agriculture (Meyer et al. 2018, Rodrigues et al. 2013). Alpha diversity of Amazonian pastureland soil bacteria was found to be higher relative to forest soil, but beta diversity was significantly lower in pasture soils (suggesting a more homogenous microbial community); the decrease in beta diversity was driven by the loss of forest soil bacteria with restricted ranges (Rodrigues et al. 2013). In the case of forest plant communities, many of the species lost post-disturbance may be specialists whose distributions are closely correlated with environmental variables, whereas species growing successfully after disturbance might be more generalized in their environmental requirements (Harrelson and Matlack 2006). Species with a generalist strategy are thought to be better adapted to heterogeneous or disturbed environments, while many specialists likely require stable environments (Clavel et 
al. 2010). The decrease in specialized species in response to disturbance, and the increase in community similarity among sites, is thought to be one of the primary dynamics driving patterns of biotic homogenization globally (Abadie et al. 2011, Clavel et al. 2010, McKinney and Lockwood 1999).

Overall, our macrofungi survey results suggest that if Eastern Hemlock is lost from forests of the northeastern US, the beta diversity of macrofungal communities may decrease and further trends toward biotic homogenization might emerge. These results add to a growing number of studies indicating that both subtle and dramatic changes in forest community composition and ecosystem processes might occur as a key foundation species, Eastern Hemlock, is lost from the eastern US (Ellison et al. 2005, Orwig et al. 2013, Rohr et al. 2009, Snyder et al. 2002, Jackson and Bellemare 2018, Toenies et al. 2018).

\section{Soil bacterial abundance, links to fungi community?}

In addition to affecting fungal communities, the impending decline of Eastern Hemlock and the subsequent changes in soil organic horizon structure and chemical composition are likely to strongly influence bacterial communities in the forest floor. For example, ecosystem studies document increased nitrogen cycling in declining Eastern Hemlock stands relative to that found in young Black Birch forests that typically replace them (e.g., Jenkins et al. 1999, Kizlinski et al. 2002). This change in nitrogen cycling is likely driven in part by shifts in the abundance and activity of bacterial taxa involved in nitrogen mineralization and nitrification. In general, fungi are thought to play a dominant role in decomposition and nutrient cycling in soils with high $\mathrm{C}: \mathrm{N}$ ratios and more recalcitrant compounds (Myers et al. 2001), whereas bacteria might take on a greater decomposition role in soil organic horizons with lower $\mathrm{C}$ : $\mathrm{N}$ ratios and higher nutrient content. For example, soils with higher levels of fungal activity relative to bacterial activity have been found to have a significantly higher total soil carbon content, and compounds derived from fungal decomposition play a large role in organic matter accumulation in boreal forests (Bailey et al. 2002, Clemmensen et al. 2013). It is conceivable that northeastern US forest ecosystems experiencing a shift from Eastern Hemlock- to deciduous treedominance might shift along this gradient of fungal versus bacterial dominance in decomposition and nutrient cycling. Our finding of seasonal shifts in abundance of bacterial CFUs between mature Eastern Hemlock versus young Black Birch plots hints at this possibility, suggesting significantly increased bacterial activity in Black Birch soils in the fall relative to nearby Eastern Hemlock-dominated plots. Further research is needed to explore these dynamics in more detail.

\section{Conclusions}

Our study of contrasting mature Eastern Hemlock- and young Black Birchdominated forest plots at 2 sites in western Massachusetts highlights the potential for significant shifts in fungal community composition, and in the levels and timing of bacterial abundance in forest-floor environments, as regional forests lose Eastern Hemlock due to exotic insect pests. In the case of macrofungal communities, we see evidence of trends toward biotic homogenization in young Black 
Birch forests compared to mature Eastern Hemlock stands, a dynamic that has been previously hypothesized for plant and animal communities in these forests. Although overall levels of morphospecies richness did not differ significantly between Eastern Hemlock and Black Birch forest plots, these subtler trends toward homogenization and the possibility of rare species loss are concerning. Further research on this understudied, yet crucial, biotic component of forest ecosystems is needed.

\section{Acknowledgments}

We would like to thank the MacLeish Field Station's Advisory Board for support and access to the study site at the field station in Whately, MA. We would also like to thank Dr. Douglas Fraser for assistance in locating research sites on his property in Chesterfield, MA. Aliza Fassler's work on this project was supported in part by the E.B. Horner Fund of Smith College's Department of Biological Sciences and the Smith College Summer Undergraduate Research Fellowship program (SURF). Several Smith College students assisted with the macrofungi surveys and soil field work for the project, including Michelle Jackson, Sam Goss, and Elizabeth Besozzi. A student team including Jinyi Yang, Yuri Lee, Youngjoo Ahn, and Brady St. Marie assisted with bacterial CFU analyses, with additional support from Dr. Chris White Ziegler and Dr. Chris Vriezen. We are also grateful to the 2 anonymous reviewers and editor for their helpful comments on the manuscript.

\section{Literature Cited}

Abadie, J.C., N. Machon, A. Muratet, and E. Porcher. 2011. Landscape disturbance causes small-scale functional homogenization, but limited taxonomic homogenization, in plant communities. Journal of Ecology 99:1134-1142.

Anderson, P., M. Brundrett, P. Grierson, and R. Robinson. 2010. Impact of severe forest dieback caused by Phytophthora cinnamomi on macrofungal diversity in the northern jarrah forest of Western Australia. Forest Ecology and Management 259:1033-1040.

Anthony, M.A., S.D. Frey, and K.A. Stinson. 2017. Fungal community homogenization, shift in dominant trophic guild, and appearance of novel taxa with biotic invasion. Ecosphere 8:e01951.

Blagodatskaya, E.V., and T.H. Anderson. 1998. Interactive effects of $\mathrm{pH}$ and substrate quality on the fungal-to-bacterial ratio and $\mathrm{qCO}_{2}$ of microbial communities in forest soils. Soil Biology and Biochemistry 30:1269-1274.

Bailey, V.L., J.L. Smith, and H. Bolton Jr. 2002. Fungal-to-bacterial ratios in soils investigated for enhanced C sequestration. Soil Biology and Biochemistry 34:997-1007.

Brooks, R.T. 2001. Effects of the removal of overstory hemlock from hemlock-dominated forests on Eastern Redback Salamanders. Forest Ecology and Management 149:197-204.

Carey, J.H. 1993. Tsuga canadensis. In Fire Effects Information System, [Online]. US Department of Agriculture, Forest Service, Rocky Mountain Research Station, Fire Sciences Laboratory. Available online at https://www.fs.fed.us/database/feis/plants/tree/ tsucan/all.html. Accessed 12 March 2017.

Chen, Y., Z. Yuan, S. Bi, X. Wang, Y. Ye, and J.C. Svenning. 2018. Macrofungal species distributions depend on habitat partitioning of topography, light, and vegetation in a temperate mountain forest. Scientific reports 8:1-4. 
Clavel, J., R. Julliard, and V. Devictor. 2010. Worldwide decline of specialist species: Toward a global functional homogenization? Frontiers in Ecology and the Environment 9:222-228.

Cleavitt, N.L., A.K. Eschtruth, J.J. Battles, and T.J. Fahey. 2008. Bryophyte response to Eastern Hemlock decline caused by Hemlock Woolly Adelgid infestation. Journal of the Torrey Botanical Society 135:12-25.

Clemmensen, K.E., A. Bahr, O. Ovaskainen, A. Dahlberg, A. Ekblad, H. Wallander, J. Stenlid, R.D. Finlay, D.A. Wardle, and B.D. Lindahl. 2013. Roots and associated fungi drive long-term carbon sequestration in boreal forest. Science 339:1615-1618.

Cobb, R.C. 2010. Species shift drives decomposition rates following invasion by Hemlock Woolly Adelgid. Oikos 119:1291-1298.

Davidson, E.A., S.E. Trumbore, and R. Amundson. 2000. Soil warming and organic carbon content. Nature 408:789-790.

Dickie, I.A., J. Oleksyn, P.B. Reich, P. Karolewski, R. Zytkowiak, A.M. Jagodzinski, and E. Turzanska. 2006. Soil modification by different tree species influences the extent of seedling ectomycorrhizal infection. Mycorrhiza 16:73-79.

Eastwood, D.C., D. Floudas, M. Binder, A. Majcherczyk, P. Schneider, A. Aerts, F.O. Asiegbu, S.E. Baker, et al. 2011. The plant cell wall-decomposing machinery underlies the functional diversity of forest fungi. Science 333:762-765.

Ellison, A.M., M.S. Bank, B.D. Clinton, E.A. Colburn, K. Elliott, C.R. Ford, D.R.Foster, B.D. Kloeppel, et al. 2005. Loss of foundation species: Consequences for the structure and dynamics of forested ecosystems. Frontiers in Ecology and the Environment $3: 479-486$.

Ellison, A.M., A.A. Barker-Plotkin, D.R. Foster, and D.A. Orwig. 2010. Experimentally testing the role of foundation species in forests: The Harvard Forest hemlock removal experiment. Methods in Ecology and Evolution 1:168-179.

Ellison, A.M., A.A. Barker Plotkin, and S. Khalid. 2016. Foundation species loss and biodiversity of the herbaceous layer in New England forests. Forests 7:1-12.

Eschtruth, A.K., N.L. Cleavitt, J.J. Battles, R.A. Evans, and T.J. Fahey. 2006. Vegetation dynamics in declining Eastern Hemlock stands: 9 years of forest response to Hemlock Woolly Adelgid infestation. Canadian Journal of Forest Research 36:1435-1450.

Fierer, N., and R.B. Jackson. 2006. The diversity and biogeography of soil bacterial communities. Proceedings of the National Academy of Sciences USA 103:626-631.

Finzi, A.C., N. Van Breemen, and C.D. Canham. 1998a. Canopy tree-soil interactions within temperate forests: Species effects on soil carbon and nitrogen. Ecological Applications 8:440-446.

Finzi, A.C., C.D. Canham, and N. Van Breemen. 1998b. Canopy tree-soil interactions within temperate forests: Species effects on $\mathrm{pH}$ and cations. Ecological Applications $8: 447-454$.

Finzi, A.C., P.C. Raymer, M.A. Giasson, and D.A. Orwig. 2014. Net primary production and soil respiration in New England hemlock forests affected by the Hemlock Woolly Adelgid. Ecosphere 5:1-16.

Foster, D.R. 2014. Hemlock: A Forest Giant on the Edge. Yale University Press, New Haven, CT. 336 pp.

Harrelson, S.M., and G.R. Matlack. 2006. Influence of stand age and physical environment on the herb composition of second-growth forest, Strouds Run, Ohio, USA. Journal of Biogeography 33:1139-1149. 
Hibbett, D.S., and M.J. Donoghue. 2001. Analysis of character correlations among wooddecay mechanisms, mating systems, and substrate ranges in Homobasidiomycetes. Systematic Biology 50:215-242.

Hicke, J.A., C.D. Allen, A.R. Desai, M.C. Dietze, R.J. Hall, D.M. Kashian, D. Moore, K.F. Raffa, R.N. Sturrock, and J. Vogelmann. 2012. Effects of biotic disturbances on forest carbon cycling in the United States and Canada. Global Change Biology 18:7-34.

HilleRisLambers, J., A.K. Ettinger, K.R. Ford, D.C. Haak, M. Horwith, B.E. Miner, H.S. Rogers, K.S. Sheldon, J.J. Tewksbury, S.M. Waters, and S. Yang. 2013. Accidental experiments: Ecological and evolutionary insights and opportunities derived from global change. Oikos 122:1649-1661.

Ignace, D.D., A. Fassler, and J. Bellemare. 2018. Decline of a foundation tree species due to invasive insects will trigger net release of soil organic carbon. Ecosphere 9:1-13.

Ishida, T.A., K. Nara, and T. Hogetsu. 2007. Host effects on ectomycorrhizal fungal communities: insight from eight host species in mixed conifer-broadleaf forests. New Phytologist 174:430-440.

Jackson, M.R., and J. Bellemare. 2018. The potential for indirect negative effects of exotic insect species on a liverwort, Bazzania trilobata (Lepidoziaceae), mediated by the decline of a foundation tree species, Tsuga canadensis (Pinaceae). Journal of the Torrey Botanical Society 145:183-194.

Jenkins, J.C., J.D. Aber, and C.D. Canham. 1999. Hemlock Woolly Adelgid impacts on community structure and N-cycling rates in Eastern Hemlock Forests. Canadian Journal of Forest Research 29:630-645.

Jobbágy, E.G., and R.B. Jackson. 2000. The vertical distribution of soil organic carbon and its relation to climate and vegetation. Ecological Applications 10:423-436.

Kizlinski, M.L., D.A. Orwig, R.C. Cobb, and D.R. Foster. 2002. Direct and indirect ecosystem consequences of an invasive pest on forests dominated by Eastern Hemlock. Journal of Biogeography 29:1489-1503.

Klein, T., R.T. Siegwolf, and C. Körner. 2016. Belowground carbon trade among tall trees in a temperate forest. Science 352:342-344.

Kranabetter, J.M., J. Friesen, S. Gamiet, and P. Kroeger, P. 2009. Epigeous fruiting bodies of ectomycorrhizal fungi as indicators of soil fertility and associated nitrogen status of boreal forests. Mycorrhiza 19:535-548.

Kraus, T.E., R.A. Dahlgren, and R.J. Zasoski. 2003. Tannins in nutrient dynamics of forest ecosystems: A review. Plant and Soil 256:41-66.

Lilleskov, E.A., T.J. Fahey, T.R. Horton, and G.M. Lovett. 2002. Belowground ectomycorrhizal fungal community change over a nitrogen deposition gradient in Alaska. Ecology 83:104-115.

Lovett, G.M., K.C. Weathers, M.A. Arthur, and J.C. Schultz. 2004. Nitrogen cycling in a northern hardwood forest: Do species matter? Biogeochemistry 67:289-308.

Lovett, G.M., C.D. Canham, M.A. Arthur, K.C. Weathers, and R.D. Fitzhugh. 2006. Forest ecosystem responses to exotic pests and pathogens in eastern North America. Bioscience $56: 395-405$.

Lovett, G.M., M. Weiss, A.M. Liebhold, T.P. Holmes, B. Leung, K.F. Lambert, D.A. Orwig, F.T. Campbell, et al. 2016. Nonnative forest insects and pathogens in the United States: Impacts and policy options. Ecological Applications 26:1437-1455.

Maturin, L.J., and J.T. Peeler. 2001. Chapter 3. Aerobic plant count. In US Food and Drug Administration (FDA), Bacteriological Analytical Manual Online, $8^{\text {th }}$ Edition. Available online at https://www.fda.gov/food/laboratory-methods-food/bam-aerobic-plate-count. Accessed 1 April 2015. 
McCune, B., and J.B. Grace. 2002. Analysis of Ecological Communities. MjM Software Design, Gleneden Beach, OR. 300 pp.

McKinney, M.L., and J.L. Lockwood. 1999. Biotic homogenization: A few winners replacing many losers in the next mass extinction. Trends in Ecology and Evolution 14:450-453.

Meyer, K.M., I.A.B. Petersen, E. Tobi, L. Korte, and B. Bohannan. 2018. Use of RNA and DNA to identify mechanisms of microbial community homogenization. bioRxiv. Available online at https://www.biorxiv.org/content/10.1101/496679v1. Accessed 23 February 2019.

Myers, R.T., D.R. Zak, D.C. White, and A. Peacock. 2001. Landscape-level patterns of microbial community composition and substrate use in upland forest ecosystems. Soil Science Society of America Journal 65:359-367.

Olden, J.D. 2006. Biotic homogenization: A new research agenda for conservation biogeography. Journal of Biogeography 33:2027-2039.

Olden, J.D., N. LeRoy Poff, M.R. Douglas, M.E. Douglas, and K.D. Fausch. 2004. Ecological and evolutionary consequences of biotic homogenization. Trends in Ecology and Evolution 19:18-24.

Orwig, D.A., and D.R. Foster. 1998. Forest response to the introduced Hemlock Woolly Adelgid in southern New England, USA. Journal of the Torrey Botanical Society 125:60-73.

Orwig, D.A., D.R. Foster, and D.L. Mausel. 2002. Landscape patterns of hemlock decline in New England due to the introduced Hemlock Woolly Adelgid. Journal of Biogeography 29:1475-1487.

Orwig, D.A., R.C. Cobb, A.W. D’Amato, M.L. Kizlinski, and D.R. Foster. 2008. Multi-year ecosystem response to Hemlock Woolly Adelgid infestation in southern New England forests. Canadian Journal of Forest Research 38:834-843.

Orwig, D.A., A.A. Barker-Plotkin, E.A. Davidson, H. Lux, K.E. Savage, and A.M. Ellison. 2013. Foundation species loss affects vegetation structure more than ecosystem function in a northeastern USA forest. PeerJ 1:e41. DOI:10.7717/peerj.41.

Pinheiro J., D. Bates, S. DebRoy, D. Sarkar, and R Core Team. 2018. nlme: Linear and nonlinear mixed effects models. R package version 3.1-137. Available online at https:// CRAN.R-project.org/package $=$ nlme.

Phillips, R. 2010. Mushrooms and Other Fungi of North America. Firefly Books, Ltd., Buffalo, NY. 384 pp.

Post, W.M., W.R. Emanuel, P.J. Zinke, and A.G. Stangenberger. 1982. Soil carbon pools and world life zones. Nature 298:156.

Preisser, E.L., and J.S. Elkinton. 2008. Exploitative competition between invasive herbivores benefits a native host plant. Ecology 89:2671-2677.

R Core Team. 2013. R: A language and environment for statistical computing. R Foundation for Statistical Computing, Vienna, Austria.

Robertson, G.P., D.C. Coleman, C.S. Bledsoe, and P. Sollins. 1999. Standard Soil Methods for Long-Term Ecological Research. Oxford University Press, Cary, NC. 480 pp. Available online at http://ebookcentral.proquest.com/lib/uma/detail.action?docID=241674. Accessed 7 March 2019.

Rodrigues, J.L., V.H. Pellizari, R. Mueller, K. Baek, E.D.C. Jesus, F.S. Paula, B. Mirza, G.S. Hamaoui, S.M. Tsai, B. Feigl, and J.M. Tiedje. 2013. Conversion of the Amazon rainforest to agriculture results in biotic homogenization of soil bacterial communities. Proceedings of the National Academy of Sciences USA 11:988-993. 
Rogers, R.S. 1978. Forests dominated by hemlock (Tsuga canadensis): Distribution as related to site and post-settlement history. Canadian Journal of Botany 56:843-854.

Rohr, J.R., C.G. Mahan, and K.C. Kim. 2009. Response of arthropod diversity to foundation species decline: The case of the Eastern Hemlock. Forest Ecology and Management 258:1503-1510.

Simard, S.W., D.A. Perry, M.D. Jones, D.D. Myrold, D.M. Durall, and R. Molina. 1997. Net transfer of carbon between ectomycorrhizal tree species in the field. Nature 388:579-582.

Smith, J.E., R. Molina, M.M. Huso, D.L. Luoma, D. McKay, M.A. Castellano, T. Lebel, and Y. Valachovic. 2002. Species richness, abundance, and composition of hypogeous and epigeous ectomycorrhizal fungal sporocarps in young, rotation-age, and oldgrowth stands of Douglas-fir (Pseudotsuga menziesii) in the Cascade Range of Oregon, USA. Canadian Journal of Botany 80:186-204.

Smith, M.E., G.W. Douhan, A.K. Fremier, and D.M. Rizzo. 2009. Are true multihost fungi the exception or the rule? Dominant ectomycorrhizal fungi on Pinus sabiniana differ from those on co-occurring Quercus species. New Phytologist 182:295-299.

Snyder, C.D., J.A. Young, D.P. Lemarié, and D.R. Smith. 2002. Influence of Eastern Hemlock (Tsuga canadensis) forests on aquatic invertebrate assemblages in headwater streams. Canadian Journal of Fisheries and Aquatic Sciences 59:262-275.

Talbot, J.M., and A.C. Finzi. 2008. Differential effects of Sugar Maple, Red Oak, and hemlock tannins on carbon and nitrogen cycling in temperate forest soils. Oecologia 155:583-592.

Tingley, M.W., D.A. Orwig, R. Field, and G. Motzkin. 2002. Avian response to removal of a forest dominant: Consequences of Hemlock Woolly Adelgid infestations. Journal of Biogeography 29:1505-1516.

Toenies, M.J., D.A. Miller, M.R. Marshall, and G.E. Stauffer. 2018. Shifts in vegetation and avian community structure following the decline of a foundational forest species, the Eastern Hemlock. The Condor 120:489-506.

Toljander, J.F., U. Eberhardt, Y.K. Toljander, L.R. Paul, and A.F. Taylor. 2006. Species composition of an ectomycorrhizal fungal community along a local nutrient gradient in a boreal forest. New Phytologist 170:873-884.

Tomasiewicz, D.M., D.K. Hotchkiss, G.W. Reinbold, R.B. Read Jr., and P.A. Hartman. 1980. The most suitable number of colonies on plates for counting. Journal of Food Protection 43:282-286.

Tóth, B.B., and Z. Barta. 2010. Ecological studies of ectomycorrhizal fungi: An analysis of survey methods. Fungal Diversity 45:3-19.

Tyler, G. 1992. Tree species affinity of decomposer and ectomycorrhizal macrofungi in beech (Fagus sylvatica L.), oak (Quercus robur L.) and hornbeam (Carpinus betulus L.) forests. Forest Ecology and Management 47:269-284.

Vellend, M., K. Verheyen, K.M. Flinn, H. Jacquemyn, A. Kolb, H. Van Calster, G. Peterken, B.J. Graae, et al. 2007. Homogenization of forest plant communities and weakening of species-environment relationships via agricultural land use. Journal of Ecology 95:565-573.

Weber, A., J. Karst, B. Gilbert, and J.P. Kimmins. 2005. Thuja plicata exclusion in ectomycorrhiza-dominated forests: Testing the role of inoculum potential of arbuscular mycorrhizal fungi. Oecologia 143:148-156.

Webster, J.R., K. Morkeski, C.A. Wojculewski, B.R. Neiderlehner, and E.F. Benfield. 2012. Effects of hemlock mortality on streams in the southern Appalachian Mountains. American Midland Naturalist 168:112-131. 


\section{A. Fassler, J. Bellemare, and D.D. Ignace}

Weed, A.S., M.P. Ayres, and J.A. Hicke. 2013. Consequences of climate change for biotic disturbances in North American forests. Ecological Monographs 83:441-470.

Westveld, M. 1956. Nature forest vegetation zones of New England. Journal of Forestry 54:332-338.

Zukswert, J.M., J. Bellemare, A.L. Rhodes, T. Sweezy, M. Gallogly, S. Acevedo, and R.S. Taylor. 2014. Forest community structure differs, but not ecosystem processes, 25 years after Eastern Hemlock removal in an accidental experiment. Southeastern Naturalist $13: 61-87$. 
Appendix 1. Macrofungi taxa collected as fruiting bodies in mature Eastern Hemlock and young Black Birch forest plots at 2 sites in western Massachusetts. Taxa are grouped by their association with Eastern Hemlock vs. Black Birch plots, where "association" indicates $>60 \%$ of collections in 1 forest type. Putative generalist taxa (between $40-60 \%$ in both forest types) are also presented. Within categories, species are sorted by their relative strength of association with the forest type based on \% of collections in that type. Rare taxa, collected only once during the course of this 2-year study, are presented at the end of appendix, sorted by their presence in Eastern Hemlock vs. Black Birch forest plots.

Eastern Hemlock forest Black Birch forest

Macrofungi taxa \# of collections (\%) \# of collections (\%)

Eastern Hemlock-associated taxa

Basidiomycete morphospecies 58

Hygrophorus marginatus var. marginatus $\mathrm{Pk}$.

Hapalopilus nidulans (Fr.) P. Karst.

Basidiomycete morphospecies 55

Basidiomycete morphospecies 56

Cortinarius armillatus (Fr.) Fr.

Basidiomycete morphospecies 10

Lactarius morphospecies 2

Basidiomycete morphospecies 1

Basidiomycete morphospecies 3

Ramaria morphospecies 1

Lycoperdon molle Pers.

Basidiomycete morphospecies 12

Basidiomycete morphospecies 6

Basidiomycete morphospecies 7

Russula morphospecies 1

$\begin{aligned} 3(100 \%) & 0 \\ 3(100 \%) & 0 \\ 2(100 \%) & 0 \\ 2(100 \%) & 0 \\ 2(100 \%) & 0 \\ 22(96 \%) & 1(4 \%) \\ 8(89 \%) & 1(11 \%) \\ 7(87.5 \%) & 1(12.5 \%) \\ 10(83 \%) & 2(17 \%) \\ 7(77 \%) & 2(22 \%) \\ 3(75 \%) & 1(25 \%) \\ 3(75 \%) & 1(25 \%) \\ 6(75 \%) & 2(25 \%) \\ 2(67 \%) & 1(33 \%) \\ 2(67 \%) & 1(33 \%) \\ 34(63 \%) & 20(37 \%)\end{aligned}$

Forest generalist taxa

Basidiomycete morphospecies 12

Polyporous varius (Pers. Ex Fr.)

Russula morphospecies 2

Russula brevipes Pk.

Basidiomycete morphospecies 11

Pseudoarmillariella ectypoides Peck (Singer)

Basidiomycete morphospecies 57

Amanita muscaria var. formosa (Pers.)

Amanita morphospecies 1

$3(60 \%)$

$24(59 \%)$

$7(58 \%)$

$29(56 \%)$

$5(55 \%)$

$15(54 \%)$

$1(50 \%)$

$18(49 \%)$

$17(44 \%)$

Black Birch-associated taxa

Clavaria morphospecies 1

Basidiomycete morphospecies 50

Basidiomycete morphospecies 51

Basidiomycete morphospecies 52

Basidiomycete morphospecies 53

Basidiomycete morphospecies 54

Lactarius morphospecies 3

Leotia viscosa Fr.
$2(40 \%)$

17 (41\%)

5 (42\%)

$23(44 \%)$

$4(44 \%)$

$13(46 \%)$

$1(50 \%)$

19 (51\%)

$22(56 \%)$

$4(100 \%)$

$7(100 \%)$

$7(100 \%)$

$6(100 \%)$

$4(100 \%)$

$3(100 \%)$

$5(100 \%)$

$3(100 \%)$ 
Trichaptum biforme (Fr. in Klotzch) Ryv.

Trichoglossum morphospecies 1

Russula morphospecies 3

Basidiomycete morphospecies 4

Basidiomycete morphospecies 2

Basidiomycete morphospecies 5

Inocybe morphospecies 1

Leotia lubrica (Scop.) Pers.

Basidiomycete morphospecies 13

Tyromyces chioneus (Fr. ) P. Karst.

Sillius pictus (Pk.)

Hygrophorus morphospecies 1

Lactarius gerardii $\mathrm{Pk}$.

Basidiomycete morphospecies 8

Basidiomycete morphospecies 9

Boletus miniato-pallescens Smith \& Thiers

Mycena morphospecies 1

Spathularia velutipes Cke. \& Farlow

Lactarius morphospecies 1

Coltricia morphospecies 1

\# of collections (\%) \# of collections (\%)

0

0

$1(12.5 \%)$

$1(17 \%)$

$2(18 \%)$

$1(20 \%)$

$1(20 \%)$

$3(23 \%)$

$1(25 \%)$

$1(25 \%)$

$1(25 \%)$

$3(30 \%)$

$4(31 \%)$

$1(33 \%)$

$1(33 \%)$

$1(33 \%)$

7 (33\%)

$1(33 \%)$

$7(35 \%)$

$4(36 \%)$
$3(100 \%)$

$3(100 \%)$

$7(87.5 \%)$

$5(83 \%)$

$9(82 \%)$

$4(80 \%)$

$4(80 \%)$

$10(77 \%)$

$3(75 \%)$

$3(75 \%)$

$3(75 \%)$

$7(70 \%)$

$9(69 \%)$

$2(67 \%)$

$2(67 \%)$

$2(67 \%)$

$14(67 \%)$

$2(67 \%)$

$13(65 \%)$

$7(64 \%)$

Rare Taxa (single collections)

Eastern Hemlock plots

Amanita morphospecies 2

Ascomycete morphospecies 1

Basidiomycete morphospecies $14-38$ ( $n=25$ taxa)

Cantharellus morphospecies 1

Cantharellus tubaeformis Fr.

Cortinarius morphospecies $1-2(n=2$ taxa)

Hydnum morphospecies 1

Lacaria morphospecies 1

Lactarius vinaceorufescens Smith

Xerula furfuracea (Pk.)

Black Birch plots

Amanita morphospecies 3

Ascomycete morphospecies 2-4 $(n=3$ taxa)

Basidiomycete morphospecies 39-49 ( $n=11$ taxa)

Cheimonophyllum candidissimus (Berk. \& M.A. Curtis) Singer

Cortinarius morphospecies 3

Entoloma sinuatum (Bull. ex Fr.)

Ganoderma tsugae Murr.

Russula morphospecies 4

Scleroderma morphospecies 1 